The $3^{\text {rd }}$ Conf. of SSFOP "Recent Techniques in Ornamental Plants Scope”, Cairo, Egypt, 26/2/2017

Scientific J. Flowers \& Ornamental Plants

www.ssfop.com/journal

ISSN: 2356-7864

\title{
INFLUENCE OF PINCHING, SOME FERTILIZATION TREATMENTS AND SPRAYING WITH ALAR ON SOLIDAGO PLANTS A. VEGETATIVE GROWTH CHARACTERISTICS
}

\author{
A.M.Z. Sarhan ${ }^{*}$, E.I. El-Maadawy ${ }^{*}$, N.M. Arafa ${ }^{* *}$ and M.F. Gaber ${ }^{* *}$ \\ * Ornamental Horticulture Dept., Fac. Agric., Cairo Univ., Egypt. \\ ** Ornamental Plants \& Garden Landscape Res. Dept., Hort. Res. Inst., ARC, Egypt.
}

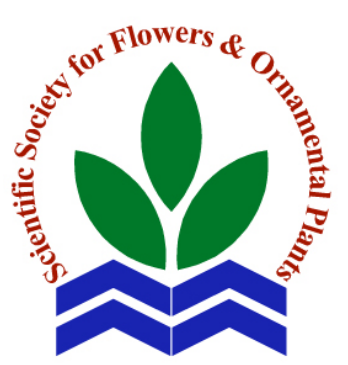

Scientific J. Flowers \& Ornamental Plants, 4(1):29-49 (2017).

Received:

11/12/2016

Accepted:

2/1/2017
ABSTRACT: An open field study was carried out at Dept. of Ornamental Hort. Fac. Agric., Cairo Univ., and the applied part was carried out at the Experimental Farm of Hort. Res. Inst., ARC., Giza, Egypt during 2015 and 2016 seasons to investigate the effect of pinching, bio- and chemical fertilization (as soil drench), foliar spraying with alar (a growth retardant) and their interactions on vegetative growth of goldenrod (Solidago hybrida, "Tara") with the aim of producing high quality plants appropriate to be used as pot plants.

Non-pinching was more effective than pinching procedure in increasing plant height, stem diameter and leaf area while pinching produced the highest values in terms of herb fresh and dry weights. Chemical fertilization with NPK at either 1.5 or $3 \mathrm{~g} /$ pot with or without bio-fertilization resulted in the highest values when compared with the other fertilization treatments. Alar at $1500 \mathrm{ppm}$ produced the highest values in of plant height, stem diameter and leaf area (first season only), while alar at zero ppm produced the heaviest fresh and dry herb weights and the widest leaves (in the second season only). Nonpinching treatments increased plant height, stem diameter and leaf area to the highest values when combined with NPK at only $1.5 \mathrm{~g} / \mathrm{pot}$, while pinching treatments combined with all fertilization treatments (except for bio-fertilizer only and control) presented the highest herb fresh and dry weights. Non-pinching in addition to alar at $1000 \mathrm{ppm}$ presented the highest values of plant height and stem diameter, while non-pinching in addition to alar at $500 \mathrm{ppm}$ produced the highest leaf area. Pinching goldenrod plants in addition to spraying with alar at zero or $500 \mathrm{ppm}$ increased herb fresh and dry weights. NPK at only 1.5 g/pot in addition to alar at 1000 or 1500 ppm produced the highest values of plant height and stem diameter. In this concern the highest fresh and dry weights were obtained by treating with bio-fertilization plus NPK at $3 \mathrm{~g} /$ pot in addition to alar at 500 or $1500 \mathrm{ppm}$. NPK at 1.5 g/pot + alar at $1500 \mathrm{ppm}$ produced the highest leaf area in the first season, while in the second one bio-fertilizer + NPK at $1.5 \mathrm{~g} / \mathrm{pot}+$ alar at zero ppm was more effective. Triple combined treatments showed a great variation in effects on vegetative growth characteristics, in general non-pinching treatments in addition to all fertilization treatments (except for bio-fertilizer only) and alar at all concentrations led to increase plant height, stem diameter and leaf area. However, 


\section{A.M.Z. Sarhan et al.}

pinching treatments in addition to bio-fertilization + NPK at $3 \mathrm{~g} / \mathrm{pot}+$ alar at either 500 or 1500 ppm presented the highest fresh and dry weights, respectively.

According to the previous findings and from an aesthetic point of view, it is recommended to treat goldenrod transplants grown in $14 \mathrm{~cm}$ pots with pinching in addition to bio-fertilization plus NPK at $3 \mathrm{~g} / \mathrm{pot}+$ spraying with alar at $1500 \mathrm{ppm}$ to produce high quality goldenrod plants appropriate to be used as pot plants.

Key words: Goldenrod, Solidago hybrida, "Tara", pinching, fertilization, NPK, bio-fertilizers, alar, vegetative growth.

\section{INTRODUCTION}

Goldenrod (Solidago sp.) is a genus of around 100 species of North America and Europe perennial plants. It belongs to the daisy family (Asteraceae). Scientific name comes from the Latin word solida which mean "to make whole" or "to strengthen", referring to its medicinal properties for treating arthritis, allergies, and sore throats. These plants form clumps of upright, sometimes branching stems, the upper half of which develops panicles of tiny golden yellow flowers. The elongated flower heads (panicles) are borne on stiff, branching stems and make a good cut flower for fresh or dried arrangements. The leaves may be linear, lance-shaped, or pointed oval, and usually have toothed edges. Often, by the time flowering starts in late summer, many of the lower leaves have withered somewhat. This late-flowering habit was used in the past by Native Americans as a kind of floral calendar, guiding them to when the corn would be ripe for harvest. Goldenrod could be propagated in spring from seeds, cuttings or by division (Hogan, 2004; Carter et al., 2007).

Pinching is one of the most suitable tactics for successful cultivation of cut flowers as well as potted plants. Removal of shoot apex by pinching the growing tip, removes the source of apical dominance and assimilates are diverted into lateral buds and branching occurs (Cline, 1991). Abou-Dahab and Habib (2005) reported that number of leaves/plant was increased by pinching at a height of $5 \mathrm{~cm}$, while, number of flowers/plant was increased by pinching at 5 or $10 \mathrm{~cm}$. The fresh and dry weights of aerial parts and roots were increased by pinching, especially at a height of $10 \mathrm{~cm}$.

It is well known that chemical fertilization is very important factor in production of ornamental plants along with other production factors. On Solidago canadensis Sodha and Dhaduk (2002) showed that the highest plant height, number of leaves, number of suckers, plant spread and fresh and dry weights of plant were recorded upon treatment with the highest nitrogen rate (150 kg N/ha). On goldenrod (Solidagi virgaurea subsp. virgaurea), Kolodziej (2007) indicated that application of $\mathrm{N}$, especially along with $\mathrm{P}$ and $\mathrm{K}$, produced higher number of dark green leaves and stems.

Bio-fertilizer is a broad term used for products containing living or dormant microorganisms such as bacteria, fungi, actinomycetes and algae alone or in combination, which on application help in fixing atmospheric $\mathrm{N}$ or solubilize/ mobilize soil nutrients in addition to secreting growthpromoting substances (Roy et al., 2006). Attia and Saad (2001) obtained an improvement in plant height, branch number/plant and herb fresh and dry weights/plant due to inoculating Catharanthus roseus plants with nitrobein at $250 \mathrm{~g} /$ fed.

Alar, as one of growth retardants, is a commercial name for daminozide among a 
lot of other names. It is generally considered safe because it has short term effect (Srivastava, 2013). Alar causes suppression of the treated plant heights, such suppression due to the action of alar as an antiauxin, with stimulation and dwarfing properties and suppression of apical dominance (Crafts et al., 1950). Namika et al. (2002) sprayed Dendranthema grandiflorum [Dendranthema morifolium] cultivars Baggi, Punjab Gold, Ratlam Selection, and Regal with alar at 500, 1000, and $1500 \mathrm{ppm}$. The results showed that alar at $1500 \mathrm{ppm}$ resulted in maximum reduction in plant height in Baggi cultivar.

This study was carried out to investigate the effect of pinching, bio- and chemical fertilization (as soil drench), foliar spraying with alar (a growth retardant) and their interactions on vegetative growth of goldenrod (Solidago hybrida, "Tara") with the aim of producing high quality goldenrod appropriate to be used as pot plants.

\section{MATERIALS AND METHODS}

This study was carried out at Dept. of Ornamental Hort., Fac. Agric., Cairo Univ., and the applied part was carried out in open field at the Experimental Farm of Hort. Res. Inst., ARC, Giza, Egypt during 2015 and 2016 seasons to investigate the effect of pinching, bio- and chemical fertilization (as soil drench), foliar spraying with alar (a growth retardant) and their interactions on vegetative growth of goldenrod (Solidago hybrida, "Tara") with the aim of producing high quality goldenrod appropriate to be used as pot plants.

\section{Plant material:}

Two-months-old goldenrod (Solidago hybrida, "Tara") transplants with about 10 leaves, and $10 \mathrm{~cm}$ height were brought from Floramax Company, Mansoria, Giza. Transplants were planted on Jan. $1^{\text {st }}$ (in both seasons) in $14 \mathrm{~cm}$ pots filled with a medium containing (1:1:1, peatmoss, vermiculite and sand $\mathrm{v} / \mathrm{v} / \mathrm{v})$.

After planting, all plants were exposed to additional light (to extend the day length to
16 hours) for approximately 8 weeks to delay flowering until producing a strong vegetative growth. The additional light was provided by using 100 watt lamps placed at height of $1.5 \mathrm{~m}$. above plants with 3 meters in between.

\section{Experiment treatments:}

\section{Pinching treatments:}

After one month from planting only one time pinching treatment was done by cutting the plants at height of $7 \mathrm{~cm}$ from the top surface of the pot. In this regard, the experimental plants were divided in to two groups; the first group was left without pinching while the other one was pinched as described above.

\section{Fertilization treatments:}

A liquid bio-fertilizer (combination of nitrobein [a commercial product contains a special clone of Azotobacter chroococcum bacteria, conc. $10^{6}$ cells $\left./ \mathrm{ml}\right]$ at $8 \mathrm{~cm}^{3}$ and phosphorein [a commercial product that contains a special clone of bacteria Bacillus megaterium which transfers the unavailable triphosphate to available monophosphate] at $8 \mathrm{~cm}^{3}$ mixed together in 72 liter of water). Commercial NPK crystal Nasr fertilizers (20:20:20) was used as chemical fertilization at the rate of 1.5 and $3.0 \mathrm{~g} /$ pot. Chemical composition of Crystal Nasr fertilizer is shown in Table (a).

Table a. Chemical composition of Crystal Nasr fertilizer.

\begin{tabular}{ll}
\hline N \% & 20 \\
P \% & 20 \\
K \% & 20 \\
Zn ppm & 120 \\
Fe ppm & 700 \\
Mn ppm & 420 \\
Cu ppm & 160 \\
Mo ppm & 140 \\
B ppm & 220 \\
\hline
\end{tabular}

Chemical fertilizer rates (1.5 or $3.0 \mathrm{~g} / \mathrm{pot}$ ) were divided into 6 doses at 10 days intervals, while bio-fertilizer was added only one time. Both chemical and bio-fertilizers were added as soil drench. 
The used fertilization treatments were as follow:

a. Control (without fertilization)

b. NPK at $1.5 \mathrm{~g} /$ pot.

c. NPK at $3.0 \mathrm{~g} /$ pot.

d. $200 \mathrm{ml}$ from the above mentioned liquid bio-fertilizer/pot (bio.).

e. NPK at $1.5 \mathrm{~g} /$ pot + bio.

f. NPK at $3.0 \mathrm{~g} /$ pot + bio.

\section{Alar application:}

After one month from planting, three applications of alar were done at 15 days intervals. Four concentrations were used in this study as zero, 500, 1000 and 1500 ppm. Alar was used as foliar spraying hence the plants were sprayed from above till runoff.

Interaction was done between the above mentioned treatments to present 48 treatments.

\section{Experimental layout:}

This experiment was carried out in 14 $\mathrm{cm}$ plastic pots and it was arranged in three factors completely randomized design (Factorial). The first factor was pinching treatments (2 treatments), the second factor was fertilization (6 treatments) and the third one was alar application (4 treatments). In this regard 48 treatments $(2 \times 6 \times 4)$ were applied in this study each one containing three replicates with 5 plants/replicate.

\section{Data recorded:}

At the end of each season the following data were recorded:

1- Plant height (cm).

2- Stem diameter (mm).

3- Herb fresh weight (g).

4- Herb dry weight (g): fresh herb samples were placed in a drying oven at $80{ }^{\circ} \mathrm{C}$ for 24 hours, then were weighed and re-dried several times until a constant weight for two consecutive readings were obtained.
5- Leaf area $\left(\mathrm{cm}^{2}\right)$ : hence fresh leaves were scanned using digital scanner device (BenQ, S2W $3300 \mathrm{U}$ ) and the output images were saved and subjected to leave area calculating by using ImageJ software as described by Ferreira and Rasband (2012).

\section{Statistical analysis:}

The experimental design used was completely randomized design in a factorial experiment with three factors as described by Snedecor and Cochran (1972) at 5\% probability level. The obtained data were statistically analyzed using MSTAT Computer Program (MSTAT Development Team, 1989). To verify differences among means of various treatments, means were compared using Duncan's Multiple Range Test as described by Duncan (1955).

\section{RESULTS AND DISCUSSION}

\section{a. Effect of pinching treatments:}

Data presented in Table (1) show that non-pinching was more effective than pinching procedure in increasing plant height, stem diameter and leaf area to the highest values in both seasons. On the other hand, pinching produced the highest values in terms of herb fresh and dry weights. Nonpinching recorded 50.35 and $53.43 \mathrm{~cm}$ for plant height, 3.85 and $4.04 \mathrm{~mm}$ for stem diameter and 7.79 and $7.88 \mathrm{~cm}^{2}$ for leaf area, in both seasons, respectively. However pinching procedure recorded 15.64 and $15.20 \mathrm{~g}$ for herb fresh weight and 3.24 and $3.59 \mathrm{~g}$ for herb dry weight in both seasons, respectively.

\section{b. Effect of fertilization treatments}

Data presented in Table (2) show the effect of fertilization treatments on vegetative growth characteristics of goldenrod plants. Chemical fertilization with NPK at 1.5 and $3.0 \mathrm{~g} /$ pot significantly produced the tallest plants in the first season as recorded 56.00 and $54.35 \mathrm{~cm}$ for these two treatments, respectively when compared with control (without fertilization) which recorded only $34.39 \mathrm{~cm}$ in the first season. 
Table 1. Effect of pinching treatments on some vegetative growth parameters of goldenrod (Solidago hybrida, "Tara") plants during 2015 and 2016 seasons.

\begin{tabular}{|c|c|c|c|c|c|}
\hline \multirow[b]{2}{*}{$\begin{array}{r}\text { Pinching } \\
\text { treatments }\end{array}$} & \multicolumn{5}{|c|}{$1^{\text {st }}$ season } \\
\hline & $\begin{array}{c}\text { Plant height } \\
\text { (cm) }\end{array}$ & $\begin{array}{c}\text { Stem diameter } \\
(\mathbf{m m})\end{array}$ & $\begin{array}{c}\text { Herb fresh } \\
\text { weight (g) }\end{array}$ & $\begin{array}{c}\text { Herb dry weight } \\
\text { (g) }\end{array}$ & $\begin{array}{l}\text { Leaf area } \\
\qquad\left(\mathrm{cm}^{2}\right)\end{array}$ \\
\hline Non pinching & 50.35 a & $3.85 \mathrm{a}$ & $13.30 \mathrm{~b}$ & $3.08 \mathrm{~b}$ & $7.79 \mathrm{a}$ \\
\hline \multirow[t]{2}{*}{ Pinching } & $45.03 \mathrm{~b}$ & $3.36 \mathrm{~b}$ & $15.64 \mathrm{a}$ & $3.24 \mathrm{a}$ & $6.98 \mathrm{~b}$ \\
\hline & \multicolumn{5}{|c|}{$2^{\text {nd }}$ season } \\
\hline Non pinching & $53.43 \mathrm{a}$ & $4.04 \mathrm{a}$ & $14.66 \mathrm{a}$ & $3.53 \mathrm{a}$ & $7.88 \mathrm{a}$ \\
\hline Pinching & $48.77 \mathrm{~b}$ & $3.43 \mathrm{~b}$ & $15.20 \mathrm{a}$ & 3.59 a & $6.08 \mathrm{~b}$ \\
\hline
\end{tabular}

Means having the same letter are not significantly differed at 0.05 level of probability according to Duncan's multiple range test.

Table 2. Effect of fertilization treatments on some vegetative growth parameters of goldenrod (Solidago hybrida, "Tara") plants during 2015 and 2016 seasons.

\begin{tabular}{|c|c|c|c|c|c|}
\hline \multirow[b]{2}{*}{$\begin{array}{l}\text { Fertilization } \\
\text { treatments }\end{array}$} & \multicolumn{5}{|c|}{$1^{\text {st }}$ season } \\
\hline & $\begin{array}{c}\text { Plant height } \\
\text { (cm) }\end{array}$ & $\begin{array}{c}\text { Stem diameter } \\
\text { (mm) }\end{array}$ & $\begin{array}{c}\text { Herb fresh } \\
\text { weight (g) }\end{array}$ & $\begin{array}{l}\text { Herb dry } \\
\text { weight (g) }\end{array}$ & $\begin{array}{l}\text { Leaf area } \\
\qquad\left(\mathrm{cm}^{2}\right)\end{array}$ \\
\hline Control & 34.39 c & $2.63 \mathrm{~d}$ & $5.39 \mathrm{~b}$ & $1.26 \mathrm{c}$ & $5.05 \mathrm{~b}$ \\
\hline NPK at $1.5 \mathrm{~g} /$ pot & $56.00 \mathrm{a}$ & $4.54 \mathrm{a}$ & $19.36 \mathrm{a}$ & $4.00 \mathrm{~b}$ & $8.98 \mathrm{a}$ \\
\hline NPK at 3 g/pot & $54.35 \mathrm{ab}$ & $4.20 \mathrm{~b}$ & $19.29 \mathrm{a}$ & $4.21 \mathrm{a}$ & $9.16 \mathrm{a}$ \\
\hline Bio. & $34.51 \mathrm{c}$ & $2.22 \mathrm{e}$ & $3.91 \mathrm{c}$ & $1.34 \mathrm{c}$ & $4.09 \mathrm{C}$ \\
\hline Bio.+ NPK at $1.5 \mathrm{~g} / \mathrm{pot}$ & $53.77 \mathrm{~b}$ & $4.08 \mathrm{bc}$ & $19.34 \mathrm{a}$ & $4.19 \mathrm{a}$ & $8.49 \mathrm{a}$ \\
\hline \multirow[t]{2}{*}{ Bio.+ NPK at 3 g/pot } & $53.13 \mathrm{~b}$ & $3.97 \mathrm{c}$ & $19.51 \mathrm{a}$ & $3.96 \mathrm{~b}$ & 8.55 a \\
\hline & \multicolumn{5}{|c|}{$2^{\text {nd }}$ season } \\
\hline Control & $35.74 \mathrm{c}$ & $2.46 \mathrm{c}$ & $6.24 \mathrm{~b}$ & $1.53 \mathrm{~d}$ & $4.53 \mathrm{c}$ \\
\hline NPK at $1.5 \mathrm{~g} /$ pot & 61.99 a & $4.68 \mathrm{a}$ & 19.17 a & $4.81 \mathrm{a}$ & 9.13 a \\
\hline NPK at 3 g/pot & $57.85 \mathrm{~b}$ & $4.40 \mathrm{~b}$ & $18.70 \mathrm{a}$ & $4.61 \mathrm{~b}$ & $7.96 \mathrm{~b}$ \\
\hline Bio. & $34.61 \mathrm{c}$ & $2.27 \mathrm{c}$ & $6.77 \mathrm{~b}$ & $1.42 \mathrm{~d}$ & $3.44 \mathrm{c}$ \\
\hline Bio.+ NPK at 1.5 g/pot & $58.65 \mathrm{~b}$ & $4.37 \mathrm{~b}$ & 19.77 a & $4.67 \mathrm{ab}$ & $8.40 \mathrm{ab}$ \\
\hline Bio. + NPK at 3 g/pot & $57.77 \mathrm{~b}$ & $4.22 \mathrm{~b}$ & $18.91 \mathrm{a}$ & $4.30 \mathrm{c}$ & $8.42 \mathrm{ab}$ \\
\hline
\end{tabular}

Bio. = Phosphorein + Nitrobein.

Means having the same letter are not significantly differed at 0.05 level of probability according to Duncan's multiple range test. 
In the second season fertilization with NPK only at $1.5 \mathrm{~g} /$ pot significantly produced the tallest plants $(61.99 \mathrm{~cm})$ when compared with control $(35.74 \mathrm{~cm})$.

Concerning the effect of fertilization treatments on stem diameter, chemical fertilization with NPK at $1.5 \mathrm{~g} / \mathrm{pot}$ significantly produced the thickest stems in both seasons as recorded 4.54 and $4.68 \mathrm{~mm}$ for both seasons, respectively when compared with bio-fertilization which recorded 2.22 and $2.27 \mathrm{~mm}$ in the first and second seasons, respectively.

In term of herb fresh weight there were significant differences in herb fresh weight of goldenrod plants due to using the different fertilizers. Bio-fertilization + NPK at 3 or 1.5 g/pot and Chemical fertilization with NPK only at 1.5 or $3 \mathrm{~g} /$ pot significantly produced the heaviest herb fresh weight in the first season as recorded $19.51,19.34 \mathrm{~g}$ and 19.36, $19.29 \mathrm{~g}$ for the four treatments, respectively when compared with biofertilization which recorded only $3.91 \mathrm{~g}$ in the first season. However, bio-fertilization + NPK at $1.5,3 \mathrm{~g} / \mathrm{pot}$ and chemical fertilization with NPK only at either 1.5 or 3 g/pot significantly produced the highest herb fresh weight values in the second season as recorded 19.77, 18.91g and 19.17, $18.70 \mathrm{~g}$ for the four treatments, respectively when compared with control and bio-fertilization which recorded $6.24 \mathrm{~g}$ and 6.77 in the second season without significant differences.

There were significant differences in herb dry weight of goldenrod plants due to using the different fertilizers. Chemical fertilization with NPK at $3 \mathrm{~g} /$ pot and biofertilization + NPK at $1.5 \mathrm{~g} /$ pot significantly produced the highest herb dry weight values in the first season as recorded 4.21 and 4.19 $\mathrm{g}$ for both treatments, respectively when compared with control (without fertilization) and bio-fertilization which recorded 1.26 and $1.34 \mathrm{~g}$ in the first season. However, chemical fertilization with NPK at $1.5 \mathrm{~g}$ /pot and biofertilization + NPK at $1.5 \mathrm{~g} /$ pot significantly produced the highest herb dry weight values in the second season as recorded 4.81 and
$4.67 \mathrm{~g}$ for both treatments, respectively when compared with bio-fertilization and control which recorded $1.42 \mathrm{~g}$ and 1.53 in the second season without significant differences.

Significant differences in leaf area of goldenrod plants due to using the different fertilizers were observed. Chemical fertilization with NPK at either 3.0 or 1.5 g/pot significantly produced the highest leaf area in the first season as recorded 9.16 and $8.98 \mathrm{~cm}^{2}$ for both treatments, respectively when compared with bio- fertilization which recorded 4.09 and $3.44 \mathrm{~cm}^{2}$ in the first and second seasons, respectively. In the second season fertilization with NPK only at 1.5 g/pot significantly produced the highest value $\left(9.13 \mathrm{~cm}^{2}\right)$ when compared with biofertilization and control (3.44 and $4.53 \mathrm{~cm}^{2}$ ).

\section{c. Effect of alar concentrations:}

Illustrated data in Table (3) show the effect of spraying with alar at different concentrations on vegetative growth characteristics of goldenrod plants. The influence of alar concentrations on plant height was significant. Alar at 1500 ppm was more effective than other treatments and significantly produced the tallest plants in both seasons (50.08 and $53.94 \mathrm{~cm}$ in the first and second seasons, respectively). In this concern alar at zero and $500 \mathrm{ppm}$ recorded the lowest values (45.94 and $49.79 \mathrm{~cm}$ in the first and second seasons, respectively).

Alar at 1500 ppm significantly increased stem diameter in both seasons (3.71 and 3.90 $\mathrm{mm}$ in the first and second seasons, respectively). Alar at $500 \mathrm{ppm}$ recorded only 3.36 and $3.53 \mathrm{~mm}$ in the first and second seasons, respectively.

The influence of alar concentrations on herb fresh weight of golden rod was significant. Alar at zero ppm was more effective than other treatments and significantly produced the highest herb fresh weight values in both seasons (15.07 and $15.60 \mathrm{~g}$ in the first and second seasons, respectively), while alar at 1500 concentration recorded only $13.82 \mathrm{~g}$ in the 
Table 3. Effect of alar concentrations on some vegetative growth parameters of goldenrod (Solidago hybrida, "Tara") plants during 2015 and 2016 seasons.

\begin{tabular}{|c|c|c|c|c|c|}
\hline \multirow[b]{2}{*}{$\begin{array}{l}\text { Alar } \\
\text { concentrations }\end{array}$} & \multicolumn{5}{|c|}{$1^{\text {st }}$ season } \\
\hline & $\begin{array}{l}\text { Plant height } \\
\text { (cm) }\end{array}$ & $\begin{array}{l}\text { Stem diameter } \\
(\mathbf{m m})\end{array}$ & $\begin{array}{c}\text { Herb fresh } \\
\text { weight (g) }\end{array}$ & $\begin{array}{l}\text { Herb dry weight } \\
\text { (g) }\end{array}$ & $\begin{array}{c}\text { Leaf area } \\
\left(\mathrm{cm}^{2}\right)\end{array}$ \\
\hline Zero & $45.94 \mathrm{c}$ & $3.66 \mathrm{a}$ & 15.07 a & $3.40 \mathrm{a}$ & $7.46 \mathrm{a}$ \\
\hline 500 ppm & $47.10 \mathrm{bc}$ & $3.36 \mathrm{~b}$ & $14.67 \mathrm{~b}$ & $3.07 \mathrm{~b}$ & $7.25 \mathrm{a}$ \\
\hline 1000 ppm & $47.65 \mathrm{~b}$ & $3.69 \mathrm{a}$ & $14.31 \mathrm{c}$ & $3.03 \mathrm{~b}$ & $7.19 \mathrm{a}$ \\
\hline \multirow[t]{2}{*}{1500 ppm } & 50.08 a & $3.71 \mathrm{a}$ & $13.82 \mathrm{~d}$ & $3.13 \mathrm{~b}$ & $7.64 \mathrm{a}$ \\
\hline & \multicolumn{5}{|c|}{$2^{\text {nd }}$ season } \\
\hline Zero & $50.82 \mathrm{~b}$ & 3.83 a & $15.60 \mathrm{a}$ & 3.76 a & 8.05 a \\
\hline 500 ppm & $49.79 \mathrm{~b}$ & $3.53 \mathrm{~b}$ & $15.34 \mathrm{ab}$ & $3.36 \mathrm{~b}$ & $6.53 \mathrm{~b}$ \\
\hline 1000 ppm & $49.86 \mathrm{~b}$ & $3.67 \mathrm{~b}$ & $14.37 \mathrm{~b}$ & $3.46 \mathrm{~b}$ & $6.46 \mathrm{~b}$ \\
\hline 1500 ppm & $53.94 \mathrm{a}$ & $3.90 \mathrm{a}$ & $14.40 \mathrm{~b}$ & 3.65 a & $6.88 \mathrm{~b}$ \\
\hline
\end{tabular}

Means having the same letter are not significantly differed at 0.05 level of probability according to Duncan's multiple range test.

first seasons. Alar at 1000 and 1500 concentration recorded only 14.37 and 14.40 $\mathrm{g}$ in the second season without significant differences for both treatments, respectively.

Herb dry weight of golden rod was significantly affected by spraying with the different alar concentrations. Alar at zero ppm was more effective than other treatments and significantly produced the highest herb dry weight values in both seasons (3.40 and $3.76 \mathrm{~g}$ in the first and second seasons, respectively). Alar at 1500 ppm shared alar at zero ppm without significant differences in between and recorded the second highest values in the second season as recorded $3.65 \mathrm{~g}$.

In case of leaf area there were insignificant differences between alar concentration in the first season as registered in Table (3). Alar at $1500 \mathrm{ppm}$ was more effective than other treatments and insignificantly produced the highest leaf area in the first season as recorded $7.64 \mathrm{~cm}^{2}$ when compared with all other treatments. On the other hand, alar at zero ppm recorded the highest significant leaf area in the second season $\left(8.05 \mathrm{~cm}^{2}\right)$ when compared with alar at 1000, 500 and $1500 \mathrm{ppm}$ as recorded 6.46,
6.53, 6.88 in the second seasons, respectively.

\section{d. Effect of interaction between pinching and fertilization treatments:}

Data presented in Table (4) reveal the effect of interaction between pinching and fertilization treatments on vegetative growth characteristics of goldenrod plants. Left plants without pinching in addition to fertilizing with NPK at $1.5 \mathrm{~g} /$ pot produced the highest values of plant height in both seasons and recorded 59.80 and $65.10 \mathrm{~cm}$ in the first and second seasons, respectively. In this concern, biofertilization produced the shortest plants when combined with pinching procedure as recorded $33.69 \mathrm{~cm}$, in the first season, while in the second one control plants (without fertilization) produced the lowest value $(31.57 \mathrm{~cm})$ when combined with pinching procedure.

There were significant differences of interaction between pinching and fertilization treatments on stem diameter, left plants without pinching in addition to fertilizing with NPK at $1.5 \mathrm{~g} /$ pot produced the highest values in both seasons and recorded 4.83 and $5.09 \mathrm{~mm}$ in the first and 
A.M.Z. Sarhan et al.

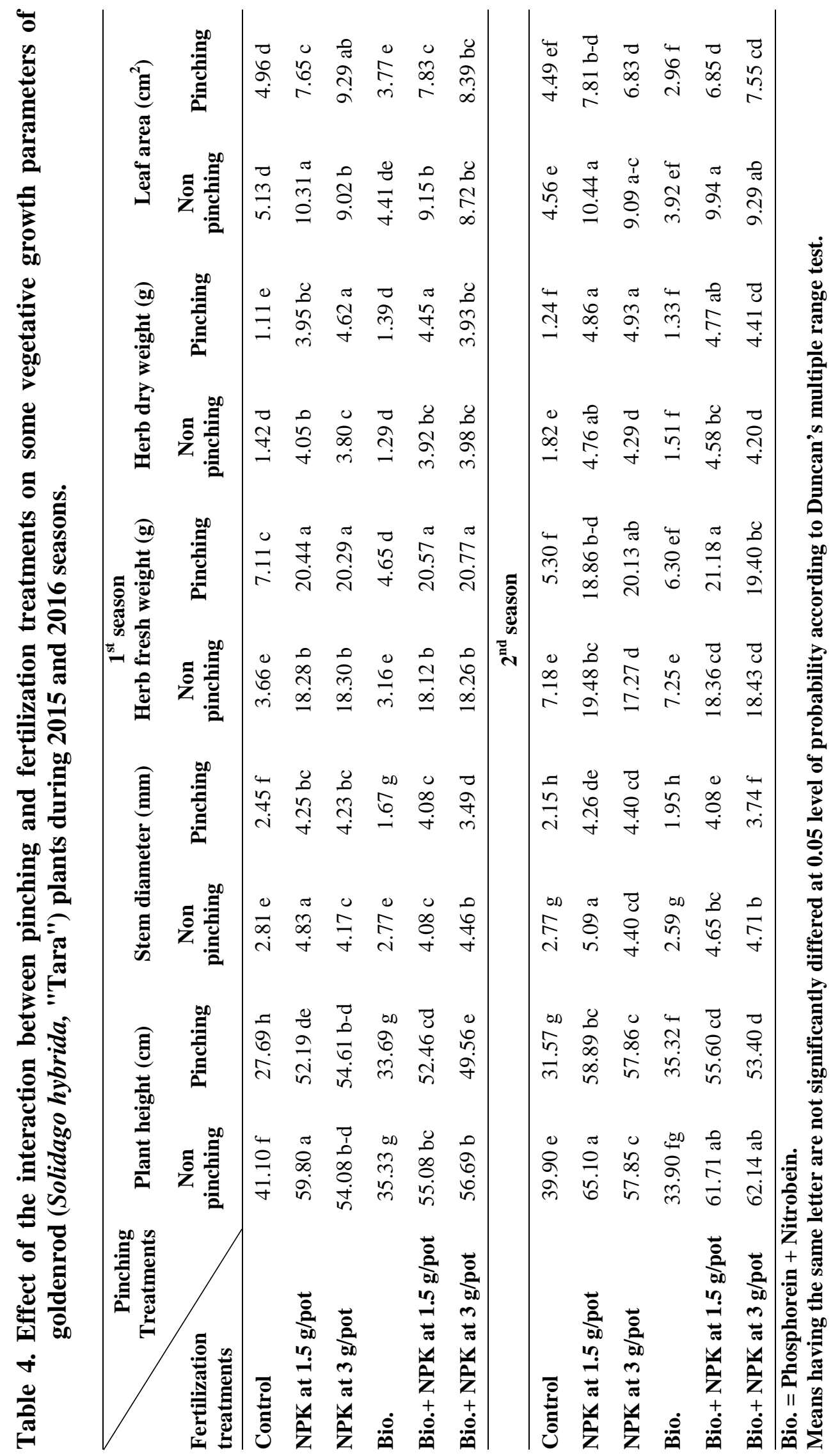


second seasons, respectively. In this concern, bio-fertilization produced the lowest stem diameter when combined with pinching procedure as recorded 1.67 and 1.95 in the first and second seasons, respectively.

In term of herb fresh weight, pinching in addition to bio-fertilization + NPK at 3 or $1.5 \mathrm{~g} / \mathrm{pot}$ and chemical fertilization with NPK only at 1.5 or $3 \mathrm{~g} /$ pot significantly produced the highest herb fresh weight values in the first season as recorded 20.77, $20.57 \mathrm{~g}$ and 20.44, $20.29 \mathrm{~g}$ for these four treatments, respectively when compared with bio-fertilization and control without pinching which recorded only 3.16 and $3.66 \mathrm{~g}$ in the first season. However, pinching in addition bio-fertilization + NPK at 3 g/pot and chemical fertilization with NPK at $3 \mathrm{~g} / \mathrm{pot}$ significantly produced the highest herb fresh weight values in the second season as recorded 21.18 and $20.13 \mathrm{~g}$ for these two treatments, respectively when compared with control and bio-fertilization combined with pinching which recorded $5.30 \mathrm{~g}$ and 6.30 in the second season without significant differences.

Pinching in addition to chemical fertilization with NPK at $3 \mathrm{~g} /$ pot and biofertilization + NPK at 1.5 g/pot significantly produced the highest herb dry weight values in the first and second seasons respectively as recorded 4.62, $4.45 \mathrm{~g}$ and 4.93, $4.77 \mathrm{~g}$ when compared with control with pinching which recorded 1.11 and $1.24 \mathrm{~g}$ in the first and second season, respectively.

Regarding leaf area, left plants without pinching in addition to fertilizing with NPK at $1.5 \mathrm{~g} /$ pot produced the highest leaf area values in both seasons and recorded 10.31 and $10.44 \mathrm{~cm}^{2}$ in the first and second seasons, respectively. In this concern, bio fertilization produced the lowest values when combined with pinching procedure as recorded 3.77 and $2.96 \mathrm{~cm}^{2}$ in the first and second seasons, respectively.

\section{e. Effect of interaction between pinching treatments and alar concentrations:}

Table (5) show the effect of the interaction between pinching and alar concentrations on vegetative growth of goldenrod plants. Non-pinched goldenrod plants significantly produced the highest values of plant height when combined with alar concentration at $1000 \mathrm{ppm}$ in both seasons (55.69 and $57.27 \mathrm{~cm}$ in the first and second seasons, respectively). Pinching procedure, on the other hand, produced the lowest plant height value when combined with alar at $1000 \mathrm{ppm}$ as recorded $39.62 \mathrm{~cm}$ in the first season and $42.45 \mathrm{~cm}$ in the second one.

In the same manner it can be observed that non-pinched goldenrod plants significantly produced the highest values of stem diameter when combined with alar concentration at $1000 \mathrm{ppm}$ in both seasons (4.12 and $4.19 \mathrm{~mm}$ in the first and second seasons, respectively). Pinching procedure, on the other hand, produced the lowest stem diameter value when combined with alar at $500 \mathrm{ppm}$ and alar at $1000 \mathrm{ppm}$ as recorded 3.27 and $3.27 \mathrm{~mm}$ in the first season and $3.32 \mathrm{~mm}$ and $3.15 \mathrm{~mm}$ in the second one for the first and second treatments, respectively.

For of herb fresh weight it could be noticed that pinched goldenrod plants significantly produced the highest values of herb fresh weight when combined with alar concentration at zero ppm in the first season (16.85 g), while non-pinching, on the other hand, produced the lowest herb fresh weight value when combined with alar at 1500 , zero, 500 and 1000 ppm as recorded 13.12, $13.30,13.35$ and $13.41 \mathrm{~g}$ in the first season for each treatment, respectively. In the second season pinched goldenrod plants significantly produced the highest values of herb fresh weight when combined with alar concentration at $500 \mathrm{ppm}$ (17.41 g). NonPinching, on the other hand, produced the lowest herb fresh weight value when combined with alar at $500 \mathrm{ppm}$ as recorded $13.26 \mathrm{~g}$ in the same season.

Concerning herb dry weight, it could be observed from the recorded data that pinched goldenrod plants significantly produced the 
A.M.Z. Sarhan et al.

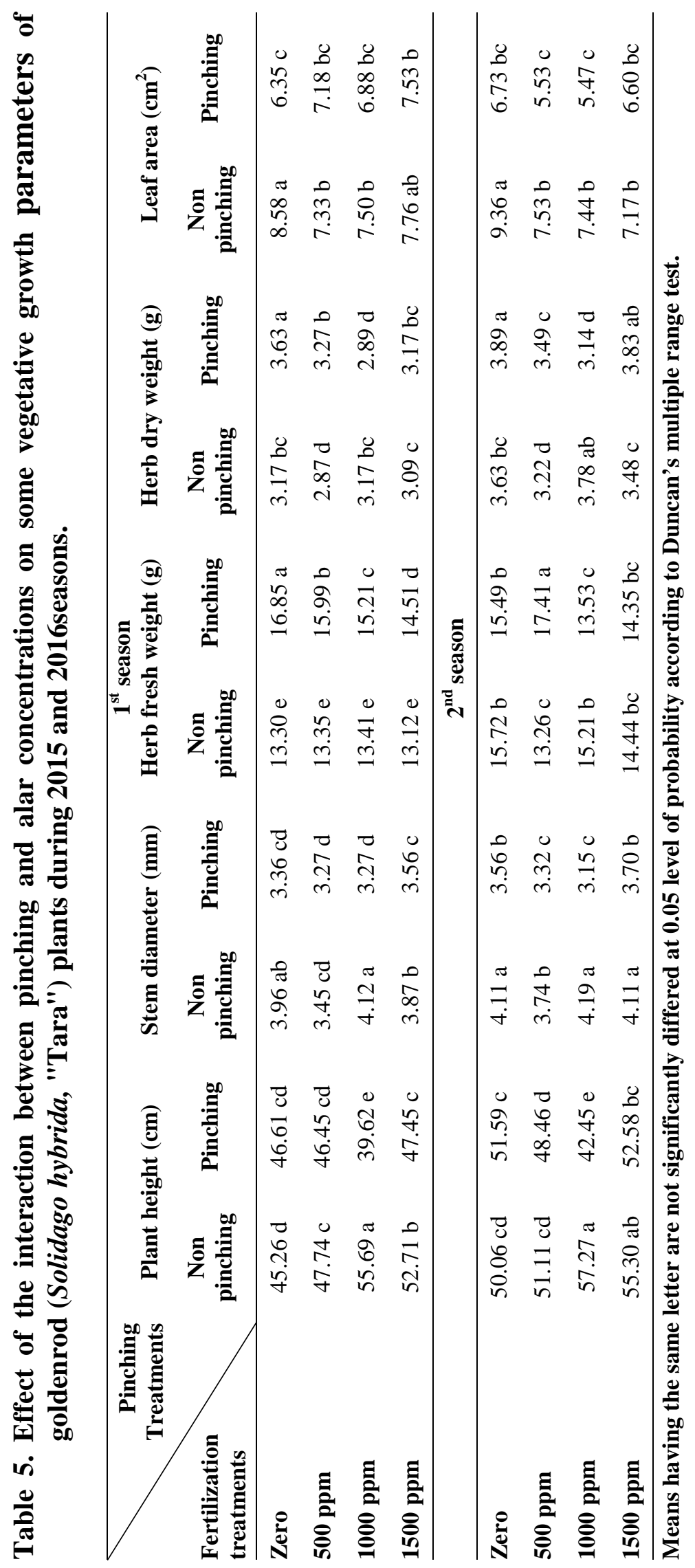


highest values of herb dry weight when combined with alar concentration at zero ppm in the first and second seasons as recorded (3.63 and $3.89 \mathrm{~g}$ ) respectively. Non-pinching, on the other hand, produced the lowest herb dry weight value when combined with alar at $500 \mathrm{ppm}$ as recorded $2.87 \mathrm{~g}$ in the first season. Pinching procedure, on the other hand, produced the lowest herb dry weight value when combined with alar at $1000 \mathrm{ppm}$ as recorded $3.14 \mathrm{~g}$ in the second season.

It can be observed from registered data that non-pinched goldenrod plants significantly produced the highest values of leaf area when combined with alar concentration at zero $\mathrm{ppm}$ in both seasons (8.58 and $9.36 \mathrm{~cm}^{2}$ in the first and second seasons, respectively). On the other hand, pinching procedure produced the lowest leaf area value when combined with alar at zero ppm as recorded $6.35 \mathrm{~cm}^{2}$ in the first season, while Pinching procedure produced the lowest leaf area value when combined with alar at $1000 \mathrm{ppm}$ as recorded $5.47 \mathrm{~cm}^{2}$ in the second season.

\section{f. Effect of the interaction between fertilization treatments and alar concentration:}

The effect of the interaction between fertilization treatments and alar concentration are shown in Table (6). The combined treatment between chemical fertilization (NPK) at $3 \mathrm{~g} / \mathrm{pot}$ and alar concentration at $1000 \mathrm{ppm}$ produced the highest significant value of plant height in the first season $(62.83 \mathrm{~cm})$. NPK at $1.5 \mathrm{~g} / \mathrm{pot}$ in addition to alar concentration at $1500 \mathrm{ppm}$ shared the previous combined treatment in its effect but came in the second position without significant difference as recorded $60.11 \mathrm{~cm}$ in the first season. On the other hand, NPK at $1.5 \mathrm{~g} /$ pot in addition to alar at 1500 ppm shared many other combined treatments and produced the highest insignificant value $(65.42 \mathrm{~cm})$ in the second season. Biofertilization in addition to alar at $1500 \mathrm{ppm}$ produced the lowest values in both seasons ( 28.39 and $25.28 \mathrm{~cm}$ in the first and second seasons, respectively).

Combined treatment between chemical fertilization (NPK) at $3 \mathrm{~g} /$ pot and alar concentration at $1000 \mathrm{ppm}$ produced the highest significant value of stem diameter in both seasons as recorded $4.70 \mathrm{~mm}$ and 4.83 $\mathrm{mm}$ in the first and second seasons, respectively. On the other hand, NPK at 1.5 $\mathrm{g} /$ pot in addition to alar at $1500 \mathrm{ppm}$ shared the previous combined treatment in its effect but came in the second position without significant difference as recorded $4.67 \mathrm{~mm}$ and $4.81 \mathrm{~mm}$ in the first and second seasons, respectively), while chemical fertilization (zero) and alar concentration at 500 ppm produced the lowest significant value of stem diameter in the first season $(2.02 \mathrm{~mm})$. However NPK (zero) and alar concentration at $1000 \mathrm{ppm}$ produced the lowest significant value of stem diameter in the second season (1.89 mm).

Interaction treatment between biofertilization $+(\mathrm{NPK})$ at $3 \mathrm{~g} /$ pot and alar concentration at $500 \mathrm{ppm}$ produced the highest significant value of herb fresh weight in the first and second seasons, respectively (20.91 and $21.07 \mathrm{~g}$ ). Bio-fertilization in addition to alar at 500, 1500, $1000 \mathrm{ppm}$ and control (zero NPK) in addition to Alar at 500 and $1500 \mathrm{ppm}$ produced the lowest values (3.60, 3.62, 4.02, 3.82 and $4.18 \mathrm{~g}$ in the first season). Bio-fertilization in addition to alar at $1500 \mathrm{ppm}$ and control (zero NPK) in addition to alar at $500 \mathrm{ppm}$ produced the lowest values (2.79 $\mathrm{g}$ and $3.23 \mathrm{~g}$ ) in the second season.

Bio-fertilization + (NPK) at $3 \mathrm{~g} /$ pot in addition to spraying with alar at $1500 \mathrm{ppm}$ produced the highest significant value of herb dry weight (5.16 and $5.46 \mathrm{~g}$ in the first and second seasons, respectively). Biofertilization in addition to alar at $1500 \mathrm{ppm}$ produced the lowest values $(0.84$ and $0.79 \mathrm{~g}$ in the first and second seasons, respectively.

Combined treatment between chemical fertilization (NPK) at $1.5 \mathrm{~g} / \mathrm{pot}$ and alar concentration at $1500 \mathrm{ppm}$ produced the 
A.M.Z. Sarhan et al.

Table 6. Effect of the interaction between fertilization treatments and alar concentrations on some vegetative growth parameters of goldenrod (Solidago hybrida, "Tara") plants during 2015 and 2016 seasons.

\begin{tabular}{|c|c|c|c|c|c|c|c|c|}
\hline \multirow{3}{*}{$\begin{array}{l}\text { Fertilization } \\
\text { treatments }\end{array}$} & \multicolumn{8}{|c|}{ Plant height (cm) } \\
\hline & \multicolumn{4}{|c|}{$1^{\text {st }}$ season } & \multicolumn{4}{|c|}{$2^{\text {nd }}$ season } \\
\hline & Zero & 500 ppm & 1000 ppm & 1500 ppm & Zero & 500 ppm & 1000 ppm & 1500 ppm \\
\hline Control & $31.39 \mathrm{kl}$ & $32.58 \mathrm{jk}$ & $29.18 \mathrm{kl}$ & $44.42 \mathrm{i}$ & $35.25 \mathrm{gh}$ & $30.14 \mathrm{~h}-\mathrm{j}$ & $26.86 \mathrm{ij}$ & $50.69 \mathrm{e}$ \\
\hline NPK at $1.5 \mathrm{~g} / \mathrm{pot}$ & $50.50 \mathrm{gh}$ & 58.89 bc & $54.50 \mathrm{~d}-\mathrm{f}$ & $60.11 \mathrm{ab}$ & $60.33 \mathrm{a}-\mathrm{c}$ & $61.92 \mathrm{ab}$ & $60.31 \mathrm{a}-\mathrm{c}$ & 65.42 a \\
\hline NPK at 3 g/pot & $50.83 \mathrm{f}-\mathrm{h}$ & $49.00 \mathrm{~h}$ & $62.83 \mathrm{a}$ & 54.72 de & 54.03 de & 55.42 c-e & $63.22 \mathrm{ab}$ & $58.75 \mathrm{~b}-\mathrm{d}$ \\
\hline Bio. & $41.17 \mathrm{i}$ & $36.28 \mathrm{j}$ & $32.22 \mathrm{k}$ & 28.391 & $41.83 \mathrm{f}$ & $39.58 \mathrm{fg}$ & 31.75 hi & $25.28 \mathrm{j}$ \\
\hline Bio.+ NPK at $1.5 \mathrm{~g} / \mathrm{pot}$ & $53.39 \mathrm{e}-\mathrm{g}$ & $52.00 \mathrm{e}-\mathrm{h}$ & $51.92 \mathrm{e}-\mathrm{h}$ & $57.78 \mathrm{~b}-\mathrm{d}$ & $58.14 \mathrm{~b}-\mathrm{d}$ & $56.22 \mathrm{~cd}$ & $58.36 \mathrm{~b}-\mathrm{d}$ & $61.89 \mathrm{ab}$ \\
\hline \multirow[t]{2}{*}{ Bio.+ NPK at 3 g/pot } & $48.33 \mathrm{~h}$ & $53.83 \mathrm{e}-\mathrm{g}$ & 55.25 c-e & 55.08 de & 55.36 с-е & 55.44 c-e & $58.67 \mathrm{~b}-\mathrm{d}$ & $61.61 \mathrm{ab}$ \\
\hline & \multicolumn{8}{|c|}{ Stem diameter (mm) } \\
\hline Control & $2.83 \mathrm{fg}$ & $2.02 \mathrm{i}$ & $2.53 \mathrm{gh}$ & $3.14 \mathrm{f}$ & $2.62 \mathrm{i}$ & $2.14 \mathrm{jk}$ & $1.89 \mathrm{k}$ & $3.19 \mathrm{~h}$ \\
\hline NPK at $1.5 \mathrm{~g} / \mathrm{pot}$ & $4.69 \mathrm{a}$ & $4.25 \mathrm{bc}$ & $4.56 \mathrm{ab}$ & $4.67 \mathrm{a}$ & $4.78 a b$ & $4.61 \mathrm{a}-\mathrm{c}$ & $4.51 \mathrm{a}-\mathrm{d}$ & $4.81 \mathrm{a}$ \\
\hline NPK at 3 g/pot & 3.83 de & $4.19 \mathrm{~b}-\mathrm{d}$ & & & $4.20 \mathrm{~d}-\mathrm{g}$ & $4.19 \mathrm{~d}-\mathrm{g}$ & & $4.40 \mathrm{~b}-\mathrm{f}$ \\
\hline Bio. & $2.17 \mathrm{hi}$ & $2.03 \mathrm{i}$ & $2.42 \mathrm{~h}$ & 2.25 hi & $2.40 \mathrm{ij}$ & $2.20 \mathrm{jk}$ & $2.41 \mathrm{ij}$ & $2.09 \mathrm{jk}$ \\
\hline Bio.+ NPK at 1.5 g/pot & 4.06 c-e & $3.81 \mathrm{e}$ & 4.14 c-e & 4.33 a-c & $4.53 \mathrm{a}-\mathrm{d}$ & $4.08 \mathrm{e}-\mathrm{g}$ & 4.33 c-g & $4.53 \mathrm{a}-\mathrm{d}$ \\
\hline \multirow[t]{2}{*}{ Bio.+ NPK at 3 g/pot } & $4.39 \mathrm{a}-\mathrm{c}$ & 3.86 de & 3.83 de & $3.81 \mathrm{e}$ & 4.47 a-e & $3.99 \mathrm{~g}$ & $4.03 \mathrm{fg}$ & $4.40 \mathrm{~b}-\mathrm{g}$ \\
\hline & \multicolumn{8}{|c|}{ Herb fresh weight (g) } \\
\hline Control & & $3.82 \mathrm{jk}$ & & & & & & 8.37 ef \\
\hline NPK at $1.5 \mathrm{~g} /$ pot & $19.26 \mathrm{c}-\mathrm{f}$ & $20.03 \mathrm{~b}$ & $19.16 \mathrm{~d}-\mathrm{g}$ & $18.99 \mathrm{~d}-\mathrm{g}$ & $20.12 \mathrm{ab}$ & $19.74 \mathrm{a}-\mathrm{c}$ & $17.46 \mathrm{~cd}$ & $19.36 \mathrm{a}-\mathrm{c}$ \\
\hline NPK at 3 g/pot & $19.14 \mathrm{~d}-\mathrm{g}$ & 19.94 bc & 19.63 b-e & $18.47 \mathrm{~g}$ & $19.97 \mathrm{ab}$ & $18.58 \mathrm{~b}-\mathrm{d}$ & $19.80 \mathrm{a}-\mathrm{c}$ & $16.46 \mathrm{~d}$ \\
\hline Bio. & $4.38 \mathrm{ij}$ & $3.60 \mathrm{k}$ & $4.02 \mathrm{i}-\mathrm{k}$ & $3.62 \mathrm{jk}$ & $9.16 \mathrm{e}$ & 8.14 ef & 7.01 ef & $2.79 \mathrm{~g}$ \\
\hline Bio.+ NPK at $1.5 \mathrm{~g} / \mathrm{pot}$ & 19.46 b-f & $19.71 \mathrm{~b}-\mathrm{d}$ & $19.41 \mathrm{~b}-\mathrm{f}$ & $18.80 \mathrm{fg}$ & 18.95 a-c & 21.27 a & $18.96 \mathrm{a}-\mathrm{c}$ & $19.90 \mathrm{ab}$ \\
\hline \multirow[t]{2}{*}{ Bio.+ NPK at 3 g/pot } & 19.38 b-f & $20.91 \mathrm{a}$ & 18.93 e-g & $18.85 \mathrm{fg}$ & $18.64 \mathrm{~b}-\mathrm{d}$ & $21.07 \mathrm{a}$ & & 19.49 a-c \\
\hline & \multicolumn{8}{|c|}{ Herb dry weight (g) } \\
\hline Control & $1.18 \mathrm{kl}$ & $0.69 \mathrm{~m}$ & $1.42 \mathrm{k}$ & & $1.47 \mathrm{j}$ & $0.89 \mathrm{k}$ & & $2.01 \mathrm{i}$ \\
\hline NPK at $1.5 \mathrm{~g} / \mathrm{pot}$ & $4.45 \mathrm{c}$ & $4.87 \mathrm{~b}$ & & & $4.88 \mathrm{~cd}$ & $5.34 \mathrm{ab}$ & 4.67 de & 4.35 ef \\
\hline NPK at 3 g/pot & $5.15 \mathrm{a}$ & $3.81 \mathrm{e}$ & $4.18 \mathrm{~d}$ & 3.71 ef & $5.29 \mathrm{ab}$ & $3.78 \mathrm{~g}$ & 5.08 a-c & 4.30 ef \\
\hline Bio. & $1.27 \mathrm{kl}$ & $1.14 \mathrm{l}$ & $2.12 \mathrm{i}$ & $0.84 \mathrm{~m}$ & $1.43 \mathrm{j}$ & $1.52 \mathrm{j}$ & $1.93 \mathrm{i}$ & $0.79 \mathrm{k}$ \\
\hline Bio.+ NPK at $1.5 \mathrm{~g} / \mathrm{pot}$ & $4.17 \mathrm{~d}$ & $4.27 \mathrm{~cd}$ & $3.53 \mathrm{f}$ & $4.78 \mathrm{~b}$ & $4.83 \mathrm{~cd}$ & $4.75 \mathrm{~cd}$ & $4.10 \mathrm{fg}$ & $5.02 \mathrm{~b}-\mathrm{d}$ \\
\hline \multirow[t]{2}{*}{ Bio.+ NPK at 3 g/pot } & $4.21 \mathrm{~cd}$ & 3.65 ef & $2.82 \mathrm{~g}$ & $5.16 \mathrm{a}$ & 4.65 de & $3.88 \mathrm{~g}$ & $3.23 \mathrm{~h}$ & $5.46 \mathrm{a}$ \\
\hline & \multicolumn{8}{|c|}{ Leaf area $\left(\mathrm{cm}^{2}\right)$} \\
\hline Control & $4.81 \mathrm{jk}$ & $4.77 \mathrm{jk}$ & $4.92 \mathrm{jk}$ & $5.68 \mathrm{ij}$ & 5.84 c-e & 3.75 ef & $3.64 \mathrm{f}$ & $4.88 \mathrm{~d}-\mathrm{f}$ \\
\hline NPK at $1.5 \mathrm{~g} / \mathrm{pot}$ & $7.60 \mathrm{gh}$ & 9.69 a-d & 8.06 e-h & $10.58 \mathrm{a}$ & $9.52 \mathrm{a}$ & $8.77 \mathrm{ab}$ & $8.74 \mathrm{ab}$ & $9.48 \mathrm{ab}$ \\
\hline NPK at 3 g/pot & 9.16 a-g & 9.60 a-e & $10.09 \mathrm{ab}$ & $7.79 \mathrm{f}-\mathrm{h}$ & $8.97 \mathrm{ab}$ & $6.16 \mathrm{~cd}$ & $9.40 \mathrm{ab}$ & 7.33 bc \\
\hline Bio. & $3.81 \mathrm{k}$ & $4.18 \mathrm{jk}$ & $4.38 \mathrm{jk}$ & $3.99 \mathrm{k}$ & $4.59 \mathrm{~d}-\mathrm{f}$ & $3.07 \mathrm{f}$ & $3.20 \mathrm{f}$ & $2.91 \mathrm{f}$ \\
\hline Bio.+ NPK at $1.5 \mathrm{~g} / \mathrm{pot}$ & 9.96 a-c & 8.15 d-h & $7.27 \mathrm{~h}$ & $8.58 \mathrm{~b}-\mathrm{h}$ & $9.71 \mathrm{a}$ & $8.74 \mathrm{ab}$ & $5.97 \mathrm{~cd}$ & $9.18 \mathrm{ab}$ \\
\hline Bio.+ NPK at 3 g/pot & 9.45 a-e & $7.12 \mathrm{hi}$ & $8.41 \mathrm{c}-\mathrm{h}$ & 9.24 a-f & $9.66 \mathrm{a}$ & $8.70 \mathrm{ab}$ & $7.81 \mathrm{a}-\mathrm{c}$ & $7.53 \mathrm{a}-\mathrm{c}$ \\
\hline
\end{tabular}

Bio. = Phosphorein + Nitrobein.

Means having the same letter are not significantly differed at 0.05 level of probability according to Duncan's multiple range test. 
highest significant value of leaf area in the first season $\left(10.58 \mathrm{~cm}^{2}\right)$. NPK at $3 \mathrm{~g} /$ pot in addition to alar concentration at $1000 \mathrm{ppm}$ shared the previous combined treatment in its effect but came in the second position without significant difference as recorded $10.09 \mathrm{~cm}^{2}$. In the second season, biofertilization +NPK at $1.5 \mathrm{~g} /$ pot in addition to alar at zero ppm shared many other combined treatments (without significant differences between them) and produced the highest significant values when compared with other treatments, the values ranged from 7.53 to $9.71 \mathrm{~cm}^{2}$. Bio fertilization in addition to alar at zero ppm produced the lowest values as recorded $3.81 \mathrm{~cm}^{2}$ in the first season. Bio-fertilization in addition to alar at $1500 \mathrm{ppm}$ produced the lowest values as recorded $2.91 \mathrm{~cm}^{2}$ in the second season.

\section{g. Effect of interaction between pinching, fertilization treatments and alar concentration:}

Concerning plant height, non-pinched plants produced the tallest plants $(65.44 \mathrm{~cm})$ when combined with NPK at $1.5 \mathrm{~g} /$ pot and alar at $500 \mathrm{ppm}$, such result was significant with some treatments and insignificant with other ones in the first season. In the second season both combined treatment between non-pinching + bio-fertilization plus NPK at $3 \mathrm{~g} / \mathrm{pot}+$ alar at $1000 \mathrm{ppm}$ and non-pinching + NPK at $1.5 \mathrm{~g} / \mathrm{pot}+$ alar at 500 ppm produced the tallest plants without significant differences between them (68.66 and $67.89 \mathrm{~cm}$, respectively). Pinched plants without fertilization and with alar at 1000 ppm produced the lowest plant height as recorded 11.80 and $13.95 \mathrm{~cm}$ in the first and second seasons, respectively (Table, 7).

Effect of interaction between pinching, fertilization treatments and alar concentration was significant on stem diameter (Table, 8). In the first season nonpinched plants produced the highest stem diameter (4.95 mm) when combined with bio-fertilization plus NPK at $3 \mathrm{~g} /$ pot and alar at $1500 \mathrm{ppm}$, such result was significant with some treatments and insignificant with other ones. In the second season combined treatment between non-pinching + NPK at $1.5 \mathrm{~g} / \mathrm{pot}+$ alar at $500 \mathrm{ppm}$ produced the highest value $(5.38 \mathrm{~mm})$. Pinched plants with bio-fertilization and with alar at 1000 ppm produced the lowest stem diameter as recorded $1.11 \mathrm{~mm}$ in the first season but pinched plants without fertilization and with alar at $1000 \mathrm{ppm}$ produced the lowest stem diameter as recorded $1.23 \mathrm{~mm}$ in the second season

In the first season, pinched plants produced the highest herb fresh weight when combined with bio-fertilization + NPK at 3 $\mathrm{g} /$ pot and alar at $500 \mathrm{ppm}$ as recorded 23.06 and $25.96 \mathrm{~g}$ in the first and second seasons, respectively (Table, 9). Non- pinched plants with bio-fertilization and with alar at 500 ppm produced the lowest herb fresh weight as recorded $2.89 \mathrm{~g}$ in the first season, while pinched plants with control (without fertilization) and with alar at $500 \mathrm{ppm}$ produced the lowest herb fresh weight as recorded $1.47 \mathrm{~g}$ in the second season.

Effect of interaction between pinching, fertilization treatments and alar concentration was significant on herb dry weight (Table, 10). Pinched plants produced the highest herb dry weight when combined with bio-fertilization + NPK at $3 \mathrm{~g} / \mathrm{pot}$ and alar at $1500 \mathrm{ppm}$ (5.51 and $5.76 \mathrm{~g}$ in the first and second seasons, respectively). pinched plants in addition to bio-fertilization and with alar at $1500 \mathrm{ppm}$ produced the lowest herb dry weight as recorded $0.34 \mathrm{~g}$ in the first season, while pinched plants with control (without fertilization) and with alar at $500 \mathrm{ppm}$ produced the lowest herb dry weight as recorded $0.35 \mathrm{~g}$ in the second season.

Regarding leaf area, data presented in Table (11) show that in the first season nonpinched plants produced the highest leaf area $\left(11.87 \mathrm{~cm}^{2}\right)$ when combined with NPK at 3 $\mathrm{g} /$ pot and alar at zero ppm, such treatment was significant with some treatments and insignificant with other ones. In the second season, the two combined treatment between non-pinching + bio-fertilization plus NPK at $1.5 \mathrm{~g} / \mathrm{pot}+$ alar at zero ppm and non- 
A.M.Z. Sarhan et al.

Table 7. Effect of the interaction between pinching, fertilization treatments and alar concentrations on plant height $(\mathrm{cm})$ of goldenrod (Solidago hybrida, "Tara") plants during 2015 and 2016 seasons.

\begin{tabular}{|c|c|c|c|c|c|c|c|c|c|}
\hline \multicolumn{10}{|c|}{ Plant height $(\mathrm{cm})$} \\
\hline \multirow{3}{*}{ Pinching } & \multirow{3}{*}{ Fertilization } & \multicolumn{4}{|c|}{$1^{\text {st }}$ season } & \multicolumn{4}{|c|}{$2^{\text {nd }}$ season } \\
\hline & & \multicolumn{4}{|c|}{ Alar concentrations } & \multicolumn{4}{|c|}{ Alar concentrations } \\
\hline & & Zero & 500 ppm & 1000 ppm & 1500 ppm & Zero & 500 ppm & 1000 ppm & 1500 ppm \\
\hline \multirow{6}{*}{ 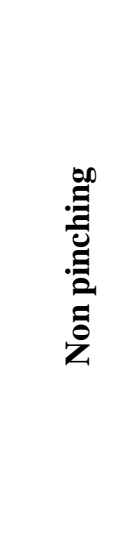 } & Control & $24.44 \mathrm{~s}$ & 44.56 ор & 46.56 l-o & $48.83 \mathrm{i}-\mathrm{o}$ & $29.61 \mathrm{p}$ & 38.28 o & 39.78 о & 51.94 i-n \\
\hline & $\begin{array}{l}\text { NPK at } 1.5 \\
\text { g/pot }\end{array}$ & 55.55 c-g & $65.44 \mathrm{a}$ & 58.22 c-e & $60.00 \mathrm{bc}$ & $61.55 \mathrm{a}-\mathrm{f}$ & 67.89 a & $65.72 \mathrm{ab}$ & $65.22 \mathrm{ab}$ \\
\hline & $\begin{array}{l}\text { NPK at } 3 \\
\text { g/pot }\end{array}$ & $52.34 \mathrm{f}-\mathrm{k}$ & $47.67 \mathrm{k}-\mathrm{o}$ & $65.22 \mathrm{ab}$ & $51.11 \mathrm{~g}-\mathrm{l}$ & $57.50 c-j$ & $54.50 \mathrm{f}-\mathrm{m}$ & $64.11 \mathrm{a}-\mathrm{d}$ & $55.28 \mathrm{e}-\mathrm{m}$ \\
\hline & Bio. & 33.34 r & $23.56 \mathrm{st}$ & 46.22 l-o & $38.22 \mathrm{qr}$ & $30.44 \mathrm{p}$ & 29.22 pq & 45.06 no & $30.89 \mathrm{p}$ \\
\hline & $\begin{array}{l}\text { Bio.+ NPK } \\
\text { at } 1.5 \mathrm{~g} / \mathrm{pot}\end{array}$ & $58.78 \mathrm{~cd}$ & $50.89 \mathrm{~g}-\mathrm{m}$ & 53.17 e-j & $57.50 \mathrm{c}-\mathrm{f}$ & $64.67 \mathrm{a}-\mathrm{c}$ & $59.67 \mathrm{~b}-\mathrm{h}$ & $60.28 \mathrm{~b}-\mathrm{g}$ & 62.22 a-e \\
\hline & $\begin{array}{l}\text { Bio.+ NPK } \\
\text { at } 3 \text { g/pot }\end{array}$ & $47.11 \mathrm{k}-\mathrm{o}$ & $54.33 \mathrm{~d}-\mathrm{h}$ & $64.72 \mathrm{ab}$ & $60.61 \mathrm{a}-\mathrm{c}$ & $56.55 \mathrm{e}-\mathrm{l}$ & $57.11 \mathrm{~d}-\mathrm{k}$ & $68.66 \mathrm{a}$ & $66.22 \mathrm{ab}$ \\
\hline \multirow{6}{*}{ } & Control & 38.33 qr & $20.61 \mathrm{~s}-\mathrm{u}$ & $11.80 \mathrm{v}$ & $40.00 \mathrm{pq}$ & 40.89 о & $22.00 \mathrm{qr}$ & $13.95 \mathrm{~s}$ & 49.44 l-n \\
\hline & $\begin{array}{l}\text { NPK at } 1.5 \\
\text { g/pot }\end{array}$ & 45.44 no & $52.33 \mathrm{f}-\mathrm{k}$ & $50.78 \mathrm{~g}-\mathrm{m}$ & $60.22 \mathrm{a}-\mathrm{c}$ & $59.11 \mathrm{~b}-\mathrm{i}$ & 55.94 e-m & $54.89 \mathrm{f}-\mathrm{m}$ & $65.61 \mathrm{ab}$ \\
\hline & $\begin{array}{l}\text { NPK at } 3 \\
\text { g/pot }\end{array}$ & 49.33 h-o & 50.33 g-n & $60.44 \mathrm{a}-\mathrm{c}$ & 58.33 c-e & 50.56 j-n & 56.33 e-l & 62.33 a-e & 62.22 a-e \\
\hline & Bio. & $49.00 \mathrm{i}-\mathrm{o}$ & $49.00 \mathrm{i}-\mathrm{o}$ & $18.22 \mathrm{u}$ & $18.55 \mathrm{tu}$ & 53.22 g-m & 49.94 k-n & 18.45 rs & 19.67 rs \\
\hline & $\begin{array}{l}\text { Bio.+ NPK } \\
\text { at } 1.5 \mathrm{~g} / \mathrm{pot}\end{array}$ & 48.00 j-o & $53.11 \mathrm{e}-\mathrm{j}$ & 50.67 g-n & 58.06 c-e & $51.61 \mathrm{j}-\mathrm{n}$ & 52.78 h-m & $56.44 \mathrm{e}-\mathrm{l}$ & $61.56 \mathrm{a}-\mathrm{f}$ \\
\hline & $\begin{array}{l}\text { Bio.+ NPK } \\
\text { at } 3 \text { g/pot }\end{array}$ & 49.56 h-o & 53.33 e-i & $45.78 \mathrm{~m}-\mathrm{o}$ & 49.56 h-o & 54.16 g-m & 53.78 g-m & $48.67 \mathrm{mn}$ & $57.00 \mathrm{~d}-\mathrm{k}$ \\
\hline
\end{tabular}

Bio. $=$ Phosphorein + Nitrobein.

Means having the same letter are not significantly differed at 0.05 level of probability according to Duncan's multiple range test. 
Table 8. Effect of the interaction between pinching, fertilization treatments and alar concentrations on stem diameter $(\mathrm{mm})$ of goldenrod (Solidago hybrida, "Tara") plants during 2015 and 2016 seasons.

\begin{tabular}{|c|c|c|c|c|c|c|c|c|c|}
\hline \multicolumn{10}{|c|}{ Stem diameter (mm) } \\
\hline \multirow{3}{*}{ Pinching } & \multirow{3}{*}{ Fertilization } & \multicolumn{4}{|c|}{$1^{\text {st }}$ season } & \multicolumn{4}{|c|}{$2^{\text {nd }}$ season } \\
\hline & & \multicolumn{4}{|c|}{ Alar concentrations } & \multicolumn{4}{|c|}{ Alar concentrations } \\
\hline & & Zero & 500 ppm & 1000 ppm & 1500 ppm & Zero & 500 ppm & 1000 ppm & 1500 ppm \\
\hline \multirow{6}{*}{ 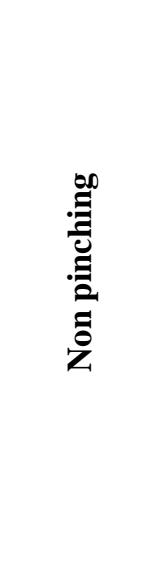 } & Control & $3.00 \mathrm{~lm}$ & $2.55 \mathrm{~m}-\mathrm{o}$ & $2.94 \mathrm{~lm}$ & $2.72 \mathrm{mn}$ & $2.78 \mathrm{r}-\mathrm{u}$ & $2.40 \mathrm{u}-\mathrm{W}$ & $2.55 \mathrm{t}-\mathrm{v}$ & 3.35 n-r \\
\hline & $\begin{array}{l}\text { NPK at } 1.5 \\
\text { g/pot }\end{array}$ & $4.89 a b$ & $4.94 \mathrm{a}$ & $4.89 a b$ & $4.61 \mathrm{a}-\mathrm{d}$ & $5.06 \mathrm{a}-\mathrm{d}$ & $5.38 \mathrm{a}$ & $5.16 \mathrm{ab}$ & 4.78 b-g \\
\hline & $\begin{array}{l}\text { NPK at } 3 \\
\text { g/pot }\end{array}$ & $4.28 \mathrm{c}-\mathrm{f}$ & $4.11 \mathrm{~d}-\mathrm{h}$ & 4.56 a-d & 3.72 g-k & $4.87 \mathrm{a}-\mathrm{f}$ & 4.24 g-l & $4.72 \mathrm{~b}-\mathrm{g}$ & $3.78 \mathrm{l}-\mathrm{o}$ \\
\hline & Bio. & $2.50 \mathrm{~m}-\mathrm{o}$ & $1.83 \mathrm{pq}$ & 3.72 g-k & $3.00 \mathrm{~lm}$ & $2.27 \mathrm{u}-\mathrm{w}$ & $2.15 \mathrm{vw}$ & 3.29 o-r & $2.68 \mathrm{~s}-\mathrm{V}$ \\
\hline & $\begin{array}{l}\text { Bio.+ NPK } \\
\text { at } 1.5 \mathrm{~g} / \mathrm{pot}\end{array}$ & $4.22 \mathrm{c}-\mathrm{g}$ & $4.00 \mathrm{e}-\mathrm{i}$ & $3.89 \mathrm{f}-\mathrm{j}$ & 4.22 c-g & $4.65 \mathrm{~b}-\mathrm{h}$ & $4.43 \mathrm{e}-\mathrm{j}$ & $4.55 \mathrm{c}-\mathrm{h}$ & 4.98 a-e \\
\hline & $\begin{array}{l}\text { Bio.+ NPK } \\
\text { at } 3 \text { g/pot }\end{array}$ & $4.89 a b$ & $3.28 \mathrm{kl}$ & $4.72 \mathrm{a}-\mathrm{c}$ & $4.95 \mathrm{a}$ & $5.01 \mathrm{a}-\mathrm{d}$ & 3.87 j-n & $4.87 \mathrm{a}-\mathrm{f}$ & $5.09 \mathrm{a}-\mathrm{c}$ \\
\hline \multirow{6}{*}{ 胞 } & Control & $2.65 \mathrm{mn}$ & $1.49 \mathrm{qr}$ & $2.11 \mathrm{op}$ & $3.56 \mathrm{i}-\mathrm{k}$ & $2.45 \mathrm{uv}$ & $1.88 \mathrm{wx}$ & $1.23 \mathrm{y}$ & $3.03 \mathrm{q}-\mathrm{t}$ \\
\hline & $\begin{array}{l}\text { NPK at } 1.5 \\
\text { g/pot }\end{array}$ & 4.50 a-e & $3.55 \mathrm{i}-\mathrm{k}$ & 4.22 c-g & $4.72 \mathrm{a}-\mathrm{c}$ & $4.50 \mathrm{~d}-\mathrm{i}$ & 3.83 k-o & 3.87 j-n & 4.83 a-f \\
\hline & $\begin{array}{l}\text { NPK at } 3 \\
\text { g/pot }\end{array}$ & 3.39 j-l & $4.27 \mathrm{c}-\mathrm{f}$ & $4.83 \mathrm{ab}$ & 4.44 a-e & $3.53 \mathrm{~m}-\mathrm{q}$ & 4.13 h-l & 4.93 a-f & $5.01 \mathrm{a}-\mathrm{d}$ \\
\hline & Bio. & $1.83 \mathrm{pq}$ & 2.22 n-p & $1.11 \mathrm{r}$ & $1.50 \mathrm{qr}$ & $2.53 \mathrm{t}-\mathrm{v}$ & $2.24 \mathrm{u}-\mathrm{W}$ & 1.54 xy & 1.50 xy \\
\hline & $\begin{array}{l}\text { Bio.+ NPK } \\
\text { at } 1.5 \mathrm{~g} / \mathrm{pot}\end{array}$ & $3.89 \mathrm{f}-\mathrm{j}$ & 3.61 h-k & 4.39 b-f & 4.44 a-e & $4.40 \mathrm{f}-\mathrm{k}$ & 3.73 l-p & $4.11 \mathrm{~h}-\mathrm{l}$ & 4.09 h-m \\
\hline & $\begin{array}{l}\text { Bio.+ NPK } \\
\text { at } 3 \text { g/pot }\end{array}$ & $3.89 \mathrm{f}-\mathrm{j}$ & 4.44 a-e & $2.94 \mathrm{~lm}$ & $2.67 \mathrm{mn}$ & 3.93 i-m & 4.11 h-l & 3.20 p-s & 3.70 l-p \\
\hline
\end{tabular}

Bio. $=$ Phosphorein + Nitrobein.

Means having the same letter are not significantly differed at 0.05 level of probability according to Duncan's multiple range test. 
A.M.Z. Sarhan et al.

Table 9. Effect of the interaction between pinching, fertilization treatments and alar concentrations on herb fresh weight (g) of goldenrod (Solidago hybrida, "Tara") plants during 2015 and 2016 seasons.

\begin{tabular}{|c|c|c|c|c|c|c|c|c|c|}
\hline \multicolumn{10}{|c|}{ Herb fresh weight (g) } \\
\hline \multirow{3}{*}{ Pinching } & \multirow{3}{*}{ Fertilization } & \multicolumn{4}{|c|}{$1^{\text {st }}$ season } & \multicolumn{4}{|c|}{$2^{\text {nd }}$ season } \\
\hline & & \multicolumn{4}{|c|}{ Alar concentrations } & \multicolumn{4}{|c|}{ Alar concentrations } \\
\hline & & Zero & 500 ppm & 1000 ppm & 1500 ppm & Zero & 500 ppm & 1000 ppm & 1500 ppm \\
\hline \multirow{6}{*}{ 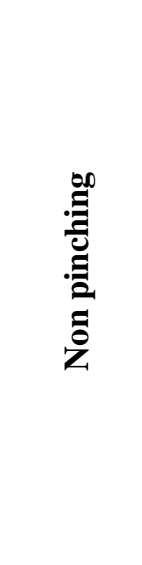 } & Control & $3.52 \mathrm{q}-\mathrm{t}$ & $3.40 \mathrm{r}-\mathrm{t}$ & $4.23 \mathrm{p}-\mathrm{s}$ & $3.47 \mathrm{q}-\mathrm{t}$ & 7.13 p-r & $4.98 \mathrm{rs}$ & $6.45 \mathrm{qr}$ & 10.15 op \\
\hline & $\begin{array}{l}\text { NPK at } 1.5 \\
\text { g/pot }\end{array}$ & $18.22 \mathrm{k}-\mathrm{m}$ & $18.91 \mathrm{i}-\mathrm{k}$ & $18.19 \mathrm{k}-\mathrm{m}$ & $17.81 \mathrm{~lm}$ & 19.49 c-g & $19.73 \mathrm{c}-\mathrm{f}$ & $20.00 c-f$ & $18.69 \mathrm{~d}-\mathrm{h}$ \\
\hline & $\begin{array}{l}\text { NPK at } 3 \\
\text { g/pot }\end{array}$ & $17.50 \mathrm{~m}$ & $18.54 \mathrm{j}-\mathrm{m}$ & $19.39 \mathrm{f}-\mathrm{j}$ & $17.76 \mathrm{~lm}$ & $19.67 \mathrm{c}-\mathrm{f}$ & $15.13 \mathrm{i}-\mathrm{l}$ & 19.77 c-f & $14.51 \mathrm{k}-\mathrm{n}$ \\
\hline & Bio. & $3.20 \mathrm{st}$ & $2.89 \mathrm{t}$ & $3.51 \mathrm{q}-\mathrm{t}$ & $3.05 \mathrm{t}$ & 11.40 no & $4.64 \mathrm{r}-\mathrm{t}$ & $9.01 \mathrm{o-q}$ & $3.95 \mathrm{r}-\mathrm{t}$ \\
\hline & $\begin{array}{l}\text { Bio.+ NPK } \\
\text { at } 1.5 \mathrm{~g} / \mathrm{pot}\end{array}$ & $18.99 \mathrm{i}-\mathrm{k}$ & $17.59 \mathrm{~m}$ & $17.67 \mathrm{~m}$ & $18.23 \mathrm{k}-\mathrm{m}$ & $19.67 \mathrm{c}-\mathrm{f}$ & $18.90 \mathrm{~d}-\mathrm{g}$ & $15.47 \mathrm{~h}-\mathrm{l}$ & 19.38 c-g \\
\hline & $\begin{array}{l}\text { Bio.+ NPK } \\
\text { at } 3 \text { g/pot }\end{array}$ & $18.38 \mathrm{j}-\mathrm{m}$ & $18.75 \mathrm{j}-\mathrm{l}$ & $17.48 \mathrm{~m}$ & $18.42 \mathrm{j}-\mathrm{m}$ & $16.98 \mathrm{f}-\mathrm{k}$ & $16.17 \mathrm{~g}-\mathrm{k}$ & 20.57 b-e & 19.99 c-f \\
\hline \multirow{6}{*}{ م: } & Control & $14.16 \mathrm{n}$ & $4.24 \mathrm{p}-\mathrm{s}$ & 5.17 op & 4.89 ор & $6.46 \mathrm{qr}$ & $1.47 \mathrm{t}$ & $6.70 \mathrm{qr}$ & $6.58 \mathrm{qr}$ \\
\hline & $\begin{array}{l}\text { NPK at } 1.5 \\
\text { g/pot }\end{array}$ & $20.29 \mathrm{c}-\mathrm{g}$ & 21.16 b-d & 20.12 d-h & $20.18 \mathrm{~d}-\mathrm{h}$ & 20.74 b-e & 19.75 c-f & $14.92 \mathrm{j}-\mathrm{m}$ & $20.03 c-f$ \\
\hline & $\begin{array}{l}\text { NPK at } 3 \\
\text { g/pot }\end{array}$ & 20.78 b-e & 21.33 bc & 19.88 e-i & 19.18 h-k & $20.27 \mathrm{c}-\mathrm{f}$ & $22.02 \mathrm{~b}-\mathrm{d}$ & 19.82 c-f & $18.42 \mathrm{e}-\mathrm{i}$ \\
\hline & Bio. & $5.55 \mathrm{o}$ & 4.30 p-r & $4.53 \mathrm{o}-\mathrm{q}$ & 4.20 p-s & 6.92 p-r & $11.64 \mathrm{~m}-\mathrm{o}$ & $5.00 \mathrm{rs}$ & $1.63 \mathrm{st}$ \\
\hline & $\begin{array}{l}\text { Bio.+ NPK } \\
\text { at } 1.5 \mathrm{~g} / \mathrm{pot}\end{array}$ & 19.92 e-i & 21.83 b & $21.15 \mathrm{~b}-\mathrm{d}$ & $19.36 \mathrm{f}-\mathrm{j}$ & $18.23 \mathrm{e}-\mathrm{j}$ & $23.64 \mathrm{ab}$ & 22.44 bc & 20.42 b-e \\
\hline & $\begin{array}{l}\text { Bio.+ NPK } \\
\text { at } 3 \text { g/pot }\end{array}$ & $20.38 c-f$ & $23.06 \mathrm{a}$ & 20.38 c-f & 19.27 g-k & $20.30 b-f$ & $25.96 \mathrm{a}$ & $12.31 \mathrm{l}-\mathrm{o}$ & $19.00 \mathrm{~d}-\mathrm{g}$ \\
\hline
\end{tabular}

Bio. = Phosphorein + Nitrobein.

Means having the same letter are not significantly differed at 0.05 level of probability according to Duncan's multiple range test. 
Table 10. Effect of the interaction between pinching, fertilization treatments and alar concentrations on herb dry weight (g) of goldenrod (Solidago hybrida, "Tara") plants during 2015 and 2016 seasons.

\begin{tabular}{|c|c|c|c|c|c|c|c|c|c|}
\hline \multicolumn{10}{|c|}{ Herb dry weight (g) } \\
\hline \multirow{3}{*}{ Pinching } & \multirow{3}{*}{ Fertilization } & \multicolumn{4}{|c|}{$1^{\text {st }}$ season } & \multicolumn{4}{|c|}{$2^{\text {nd }}$ season } \\
\hline & & \multicolumn{4}{|c|}{ Alar concentrations } & \multicolumn{4}{|c|}{ Alar concentrations } \\
\hline & & Zero & 500 ppm & 1000 ppm & 1500 ppm & Zero & 500 ppm & 1000 ppm & 1500 ppm \\
\hline \multirow{6}{*}{ 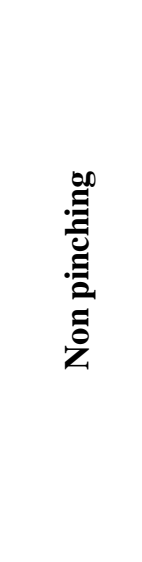 } & Control & $1.23 \mathrm{q}-\mathrm{t}$ & $1.00 \mathrm{~s}-\mathrm{u}$ & $1.36 \mathrm{q}-\mathrm{s}$ & 2.09 o & $1.51 \mathrm{u}$ & $1.42 \mathrm{u}$ & $1.76 \mathrm{~s}-\mathrm{u}$ & $2.58 \mathrm{r}$ \\
\hline & $\begin{array}{l}\text { NPK at } 1.5 \\
\text { g/pot }\end{array}$ & $4.10 \mathrm{~h}-\mathrm{k}$ & $4.51 \mathrm{e}-\mathrm{g}$ & $4.38 \mathrm{f}-\mathrm{h}$ & $3.19 \mathrm{mn}$ & $4.64 \mathrm{f}-\mathrm{k}$ & 5.07 c-g & 5.55 a-c & $3.77 \mathrm{o-q}$ \\
\hline & $\begin{array}{l}\text { NPK at } 3 \\
\text { g/pot }\end{array}$ & $4.95 \mathrm{~b}-\mathrm{d}$ & $3.44 \mathrm{~lm}$ & $3.75 \mathrm{kl}$ & $3.06 \mathrm{n}$ & $4.96 \mathrm{e}-\mathrm{h}$ & $3.49 \mathrm{q}$ & $5.00 \mathrm{~d}-\mathrm{g}$ & $3.73 \mathrm{pq}$ \\
\hline & Bio. & $0.98 \mathrm{tu}$ & $0.76 \mathrm{u}$ & $2.09 \mathrm{o}$ & $1.35 \mathrm{q}-\mathrm{s}$ & $1.22 \mathrm{u}$ & $1.35 \mathrm{u}$ & 2.24 rs & $1.22 \mathrm{u}$ \\
\hline & $\begin{array}{l}\text { Bio.+ NPK } \\
\text { at } 1.5 \mathrm{~g} / \mathrm{pot}\end{array}$ & $4.35 \mathrm{f}-\mathrm{i}$ & 4.05 h-k & $3.20 \mathrm{mn}$ & $4.08 \mathrm{~h}-\mathrm{k}$ & $5.52 \mathrm{a}-\mathrm{d}$ & $4.58 \mathrm{~g}-\mathrm{l}$ & $3.81 \mathrm{n}-\mathrm{q}$ & 4.42 h-m \\
\hline & $\begin{array}{l}\text { Bio.+ NPK } \\
\text { at } 3 \text { g/pot }\end{array}$ & $3.43 \mathrm{~lm}$ & $3.43 \mathrm{~lm}$ & $4.24 \mathrm{~g}-\mathrm{i}$ & 4.81 c-e & $3.91 \mathrm{~m}-\mathrm{q}$ & $3.42 \mathrm{q}$ & $4.31 \mathrm{k}-\mathrm{o}$ & $5.15 b-f$ \\
\hline \multirow{6}{*}{ 茴 } & Control & $1.12 \mathrm{r}-\mathrm{u}$ & $0.39 \mathrm{v}$ & $1.48 \mathrm{qr}$ & $1.45 \mathrm{qr}$ & $1.43 \mathrm{u}$ & $0.35 \mathrm{v}$ & $1.72 \mathrm{~s}-\mathrm{u}$ & $1.44 \mathrm{u}$ \\
\hline & $\begin{array}{l}\text { NPK at } 1.5 \\
\text { g/pot }\end{array}$ & 4.80 c-e & $5.22 \mathrm{ab}$ & 3.88 jk & 1.88 ор & 5.12 b-f & $5.60 \mathrm{a}-\mathrm{c}$ & $3.79 \mathrm{n}-\mathrm{q}$ & $4.92 \mathrm{e}-\mathrm{i}$ \\
\hline & $\begin{array}{l}\text { NPK at } 3 \\
\text { g/pot }\end{array}$ & 5.35 a & 4.18 g-j & $4.61 \mathrm{~d}-\mathrm{f}$ & $4.35 \mathrm{f}-\mathrm{h}$ & $5.62 \mathrm{ab}$ & 4.06 l-p & 5.15 b-f & $4.86 \mathrm{e}-\mathrm{j}$ \\
\hline & Bio. & $1.56 \mathrm{pq}$ & $1.52 \mathrm{pq}$ & $2.14 \mathrm{o}$ & $0.34 \mathrm{v}$ & $1.64 \mathrm{tu}$ & $1.69 \mathrm{tu}$ & $1.62 \mathrm{tu}$ & $0.37 \mathrm{v}$ \\
\hline & $\begin{array}{l}\text { Bio.+ NPK } \\
\text { at } 1.5 \mathrm{~g} / \mathrm{pot}\end{array}$ & 3.99 i-k & 4.48 e-g & $3.86 \mathrm{jk}$ & 5.49 a & $4.14 \mathrm{k}-\mathrm{p}$ & $4.91 \mathrm{e}-\mathrm{i}$ & 4.39 i-m & $5.61 \mathrm{ab}$ \\
\hline & $\begin{array}{l}\text { Bio.+ NPK } \\
\text { at } 3 \text { g/pot }\end{array}$ & 4.98 bc & $3.86 \mathrm{jk}$ & $1.39 \mathrm{qr}$ & $5.51 \mathrm{a}$ & 5.39 a-e & $4.33 \mathrm{j}-\mathrm{n}$ & $2.14 \mathrm{r}-\mathrm{t}$ & $5.76 \mathrm{a}$ \\
\hline
\end{tabular}

Bio. $=$ Phosphorein + Nitrobein.

Means having the same letter are not significantly differed at 0.05 level of probability according to Duncan's multiple range test. 
A.M.Z. Sarhan et al.

Table 11. Effect of the interaction between pinching, fertilization treatments and alar concentrations on leaf area $\left(\mathrm{cm}^{2}\right)$ of goldenrod (Solidago hybrida, "Tara") plants during 2015 and 2016 seasons.

\begin{tabular}{|c|c|c|c|c|c|c|c|c|c|}
\hline \multicolumn{10}{|c|}{ Leaf area $\left(\mathrm{cm}^{2}\right)$} \\
\hline \multirow{3}{*}{ Pinching } & \multirow{3}{*}{ Fertilization } & \multicolumn{4}{|c|}{$1^{\text {st }}$ season } & \multicolumn{4}{|c|}{$2^{\text {nd }}$ season } \\
\hline & & \multicolumn{4}{|c|}{ Alar concentration } & \multicolumn{4}{|c|}{ Alar concentration } \\
\hline & & Zero & 500 ppm & 1000 ppm & 1500 ppm & Zero & 500 ppm & 1000 ppm & 1500 ppm \\
\hline \multirow{6}{*}{ 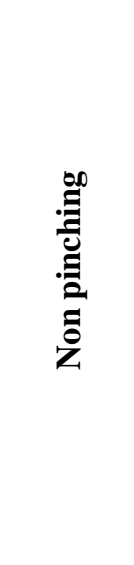 } & Control & $5.84 \mathrm{~m}-\mathrm{u}$ & $4.23 \mathrm{r}-\mathrm{v}$ & $4.33 \mathrm{q}-\mathrm{v}$ & $6.12 \mathrm{l}-\mathrm{s}$ & $5.71 \mathrm{i}-\mathrm{r}$ & 3.80 o-s & $4.15 \mathrm{n}-\mathrm{s}$ & $4.60 \mathrm{l-s}$ \\
\hline & $\begin{array}{l}\text { NPK at } 1.5 \\
\text { g/pot }\end{array}$ & 8.73 e-j & $11.57 \mathrm{a}-\mathrm{c}$ & $9.60 \mathrm{~b}-\mathrm{h}$ & $11.35 \mathrm{a}-\mathrm{d}$ & 10.16 a-e & $11.02 \mathrm{a}-\mathrm{c}$ & 10.20 a-e & 10.38 a-d \\
\hline & $\begin{array}{l}\text { NPK at } 3 \\
\text { g/pot }\end{array}$ & $11.87 \mathrm{a}$ & $9.25 \mathrm{~d}-\mathrm{i}$ & 9.41 c-i & $5.57 \mathrm{n}-\mathrm{v}$ & $12.66 \mathrm{ab}$ & $7.02 \mathrm{f}-\mathrm{n}$ & $10.45 \mathrm{a}-\mathrm{d}$ & 6.22 h-p \\
\hline & Bio. & $3.83 \mathrm{t}-\mathrm{v}$ & $5.00 \mathrm{p}-\mathrm{V}$ & $4.57 \mathrm{q}-\mathrm{V}$ & $4.22 \mathrm{r}-\mathrm{V}$ & $4.90 \mathrm{l}-\mathrm{s}$ & $3.31 \mathrm{p}-\mathrm{s}$ & $4.14 \mathrm{n}-\mathrm{s}$ & 3.35 p-s \\
\hline & $\begin{array}{l}\text { Bio.+ NPK } \\
\text { at } 1.5 \mathrm{~g} / \mathrm{pot}\end{array}$ & $11.70 \mathrm{ab}$ & $7.89 \mathrm{f}-\mathrm{m}$ & 7.59 h-n & $9.43 \mathrm{c}-\mathrm{i}$ & $13.16 \mathrm{a}$ & 10.19 a-e & 6.22 h-p & 10.19 a-e \\
\hline & $\begin{array}{l}\text { Bio.+ NPK } \\
\text { at } 3 \text { g/pot }\end{array}$ & $9.50 \mathrm{~b}-\mathrm{i}$ & $6.02 \mathrm{l-t}$ & $9.48 \mathrm{~b}-\mathrm{i}$ & 9.88 a-g & 9.57 c-g & $9.83 \mathrm{~b}-\mathrm{f}$ & $9.50 \mathrm{c}-\mathrm{g}$ & $8.28 \mathrm{c}-\mathrm{j}$ \\
\hline \multirow{6}{*}{ 哭 } & Control & $3.78 \mathrm{uv}$ & $5.31 \mathrm{o}-\mathrm{V}$ & $5.51 \mathrm{n}-\mathrm{v}$ & $5.25 \mathrm{o-v}$ & $5.96 \mathrm{~h}-\mathrm{q}$ & $3.70 \mathrm{o}-\mathrm{s}$ & 3.13 q-s & $5.16 \mathrm{k}-\mathrm{s}$ \\
\hline & $\begin{array}{l}\text { NPK at } 1.5 \\
\text { g/pot }\end{array}$ & $6.47 \mathrm{k}-\mathrm{q}$ & $7.81 \mathrm{f}-\mathrm{m}$ & $6.52 \mathrm{j}-\mathrm{q}$ & $9.81 \mathrm{a}-\mathrm{h}$ & 8.89 c-h & 6.52 g-o & 7.27 e-m & 8.58 c-i \\
\hline & $\begin{array}{l}\text { NPK at } 3 \\
\text { g/pot }\end{array}$ & $6.45 \mathrm{k}-\mathrm{r}$ & 9.95 a-g & 10.77 a-e & $10.01 \mathrm{a}-\mathrm{f}$ & $5.27 \mathrm{j}-\mathrm{s}$ & $5.29 \mathrm{j}-\mathrm{s}$ & 8.34 c-j & 8.43 c-i \\
\hline & Bio. & 3.79 uv & $3.35 \mathrm{v}$ & $4.19 \mathrm{~s}-\mathrm{V}$ & $3.76 \mathrm{uv}$ & $4.29 \mathrm{~m}-\mathrm{s}$ & 2.82 rs & $2.26 \mathrm{~s}$ & $2.47 \mathrm{~s}$ \\
\hline & $\begin{array}{l}\text { Bio.+ NPK } \\
\text { at } 1.5 \mathrm{~g} / \mathrm{pot}\end{array}$ & $8.22 \mathrm{f}-\mathrm{l}$ & $8.42 \mathrm{f}-\mathrm{k}$ & 6.95 j-p & 7.73 g-n & 6.25 h-p & 7.28 e-m & 5.71 i-r & 8.16 c-k \\
\hline & $\begin{array}{l}\text { Bio.+ NPK } \\
\text { at } 3 \text { g/pot }\end{array}$ & $9.40 \mathrm{c}-\mathrm{i}$ & $8.21 \mathrm{f}-\mathrm{l}$ & 7.33 i-o & 8.61 e-k & $9.75 \mathrm{~b}-\mathrm{f}$ & $7.56 \mathrm{~d}-\mathrm{l}$ & 6.13 h-q & $6.78 \mathrm{f}-\mathrm{o}$ \\
\hline
\end{tabular}

Bio. $=$ Phosphorein + Nitrobein.

Means having the same letter are not significantly differed at 0.05 level of probability according to Duncan's multiple range test. 
pinching + NPK at $3 \mathrm{~g} /$ pot + alar at zero ppm produced the highest values without significant differences between them (13.16 and $12.66 \mathrm{~cm}^{2}$ for both treatments, respectively). Pinched plants with biofertilization and with alar at $500 \mathrm{ppm}$ produced the lowest leaf area as recorded $3.35 \mathrm{~cm}^{2}$ in the first season, while pinched plants with bio- fertilization and with alar at $1000 \mathrm{ppm}$ produced the lowest leaf area as recorded $2.26 \mathrm{~cm}^{2}$ in the second season.

The above mentioned results were in harmony with findings of Khobragade et al. (2012) who found that pinching reduced the plant height and delayed flowering of China aster (Callistephus chinensis) cv. Poornima; Badole et al. (2015) observed that the individual increase in application of nitrogen (up to $200 \mathrm{~kg} \mathrm{~N} \mathrm{ha)} \mathrm{and} \mathrm{phosphorus} \mathrm{(up} \mathrm{to}$ $100 \mathrm{~kg} \mathrm{P}$ ha) on China-aster significantly improved the plant height, number of branches flowering at 50 per cent; Abd ElMalik (2004) reported that microbein as a bio-fertilizer augmented greatly the vegetative growth characters of Tagetes minuta plants i.e. plant height, stem diameter, branch number/plant, leaves fresh and dry weight per plant and / fed as well as, fresh and dry weights of stem branches / plant compared with untreated plants; Gautam (2006) treated Chrysanthemum morifolium Ram plants with B-nine [daminozide] at (1000, 1500, 2000 and 2500 ppm). They found that B-nine at all concentrations retarded plant height, number of nodes and internodal length over control. It could interpret the positive effects of pinching, fertilization and alar on vegetative growth as follow: apical meristem and young expanding leaves constitute a metabolic sink and auxin source that inhibit the outgrowth of lateral buds (Weiss and Shilo, 1988), on the other hand pinching simply mean removing the terminal growing portion of stem due to apical dominance. Removal of shoot apex by pinching the growing tip, removes the source of apical dominance and assimilates are diverted into lateral buds and branching occurs (Cline, 1991). Bio-fertilizer containing living or dormant micro- organisms such as bacteria, fungi, actinomycetes and algae alone or in combination, which on application help in fixing atmospheric $\mathrm{N}$ or solubilize/mobilize soil nutrients in addition to secreting growthpromoting substances. They are also known as bioinoculants or microbial cultures. Strictly speaking, although widely used, the term bio-fertilizer is a misnomer. Unlike chemical fertilizers, these are not used to provide nutrients present in them, except in the case of Azolla used as green manure (Roy et al., 2006). Alar causes suppression of the treated plant heights, such suppression due to the action of alar as an antiauxin, with stimulation and dwarfing properties and suppression of apical dominance (Crafts et al., 1950). The inhibition of shoot elongation in many plant species by growth retardants has been attributed by the influence of retardants on gibberellin biosynthesis as opined by Dennis et al. (1965) and Maynard and Barker (1972).

According to the previous findings and from an aesthetic point of view, it is recommended to treat goldenrod transplants grown in $14 \mathrm{~cm}$ pots with pinching in addition to bio-fertilization (a mixture of nitrobein and phosphorein biofertilizers) plus $\mathrm{NPK}$ at $3 \mathrm{~g} / \mathrm{pot}+$ spraying with alar at 1500 ppm to produce high quality goldenrod plants appropriate to be used as pot plants.

\section{REFERENCES}

Abd EL-Malik, M.H. (2004). Effect of Some Chemical and Biofertilization Treatments on Growth, Yield and Active Ingredients of Tagetes minuta, L. Plants. Ph.D. Thesis, Fac. Agric., Minia Univ. Egypt.

Abou-Dahab, T.A.M. and Habib, A.M.A. (2005). Production of Barleria cristata L. as a dwarf flowering pot plant. Annals of Agricultural Sci., Moshtohor, 43(2):746727.

Attia, F.A. and Saad, O.A. (2001). Biofertilizers as partial alternative of chemical fertilizer for Catharanthus roseus. J. Agric. Sci., Mansoura Univ., 26(11):7193-7208. 


\section{A.M.Z. Sarhan et al.}

Badole, W.P.; Sanap, P.B.; Vandana, K. and Bhaisare, P. (2015). Effect of nitrogen and phosphorus on nutrient uptake, yield and quality of China-aster. Journal of Soils and Crops; 25(2):397-401.

Carter, S.; Becker, C. and Lilly, B. (2007). Perennials, The Gardener's References. Timber Press, Inc., Portland, Oregon, USA, 542 pp.

Cline, M.G. (1991). Apical dominance. Bot. Rev., 57: 318-358.

Crafts, A.C.; Currier, H.B. and Day, B.E. (1950). Response of several crop plants and weeds to maleic hydrazide. Hilgardia, 20:57-80.

Dennis, D.T.; Upper, C.D. and West, C.A. (1965). An enzymatic site of inhibition of gibberellin biosynthesis by AMO 1618 and other plant growth retardants. Plant Physiol., 40:948-952.

Duncan, D.B. (1955). Multiple range and multiple $\mathrm{F}$ test. Journal of Biometrics, 11:1-42.

Ferreira, T. and Rasband, W.S. (2012). ImageJ User Guide-IJ-1.46. http://imagej. nih.gov/ij/docs/guide.

Gautam, S.K.; Sen, N.L.; Jain, M.C.; Dashora, L.K. (2006). Effect of plant regulators on growth, flowering and yield of chrysanthemum (Chrysanthemum morifolium Ram.) c.v. Nilima. Orissa Journal of Horticulture; 34(1):36-40.

Hogan, S. (2004). Flora: A Gardener's Encyclopedia. Timber Press, Inc., Portland, Oregon, USA, 1584 pp.

Khobragade, R.K.; Sharad, B.; and Thakur, R.S. (2012). Effect of planting distance and pinching on growth, flowering and yield of China aster (Callistephus chinensis) cv. Poornima. Indian Journal of Agricultural Sciences; 82(4):334-339.

Kolodziej, B. (2007). The effect of NPK fertilisation on goldenrod (Solidago virgaurea L. subsp. virgaurea) yield and quality parameters. Herba Polonica; 53(3):129-134.

Maynard, D.N. and Barker, A.V. (1972). Internal browning of Brussels sprout: A calcium deficiency disorder. J. Amer. Soc. Hort. Sci., 97:789-792.

MSTAT Development Team (1989). MSTAT user's guide: a microcomputer program for the design management and analysis of agronomic research experiments. Michigan State University, East Lansing, USA.

Namika Arora, J.S.; Singh, K. and Sidhu, G.S. (2002). Effect of ethrel and alar on chrysanthemum. Floriculture research trend in India. Proceedings of the National Symposium on Indian Floriculture in the New Millennium, LalBagh, Bangalore, 25-27 February, 2002. :139-142.

Roy, R.N.; Finck, A.; Blair, G.J. and Tandon, H.L.S. (2006). Plant Nutrition for Food Security: A Guide for Integrated Nutrient Management. Food and Agriculture Organization of the United Nations (FAO), Rome, 348 p.

Snedecor, G.W. and Cochran, W.G. (1972). Statistical Methods. $6^{\text {th }}$ ed., Iowa State College Press, Ames, Iowa, USA., 507 p.

Sodha, B.P. and Dhaduk, B.K. (2002). Effect of spacing and nitrogen on solidago. J. Ornamental Hort. (New Series), 5(1):6364.

Srivastava, R. (2013). Effect of cycocel and alar on the growth and flowering of poinsettia cv. Single. Asian Journal of Horticulture, 8(1):313-316.

Weiss, D. and Shilo, R. (1988). Axillary bud inhibition induced by young leaves or bract in Euphorbia pulcherrima Willd. Ann. Bot., 62: 435-440. 


\title{
تأثير التطويش، بعض معاملات التسميد والرش بالألار على نباتات السوليداجو أ. صفات النمو الخضري
}

\author{
عاطف محمد زكريا سرحان*، عفت اسماعيل المعداوى *، ناجي محمد حسن عرفة **$$
\text { و محمد فوزي جابر }
$$ \\ * قسم بساتين الزينة، كلية الزر اعة، جامعة القاهرة، الجيزة، مصر. \\ ** قسم بحوث الزينة و تتسيق الحدائق، معهد بحوث البساتين، مركز البحوث الزر اعية، الجيزة، مصر.
}

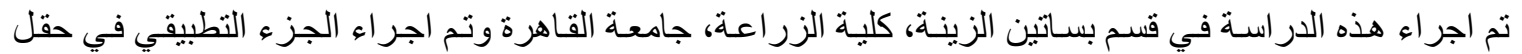

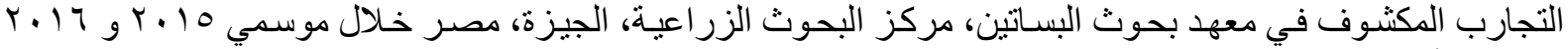

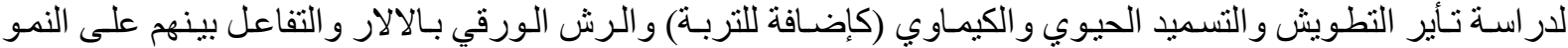
الخضري لنبات السوليداجو وذللك بهدف إنتاجه كنباتات اصص ولئيسات ذات جودة عالية.

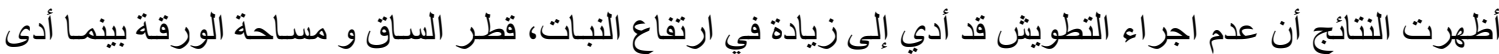

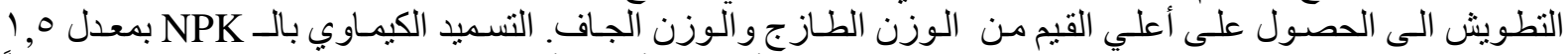

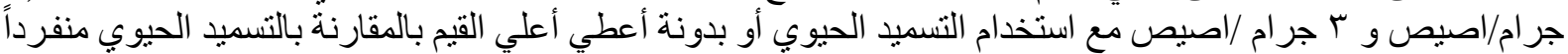

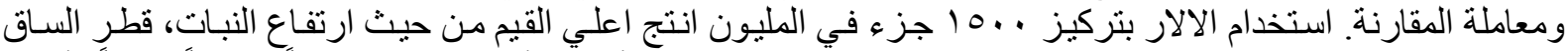

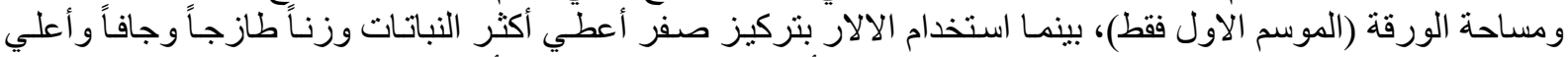

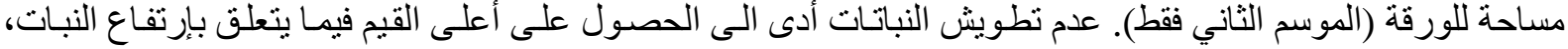

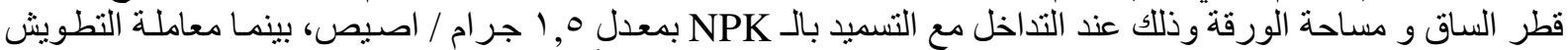

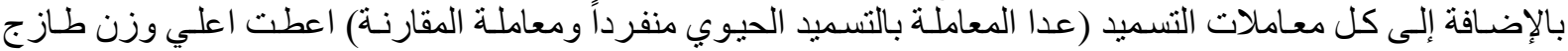

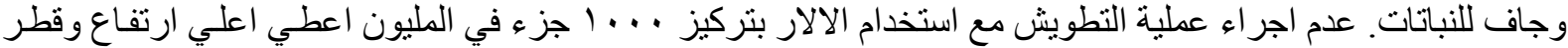

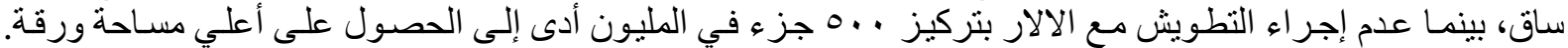

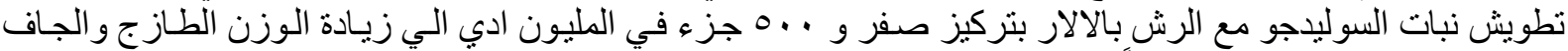

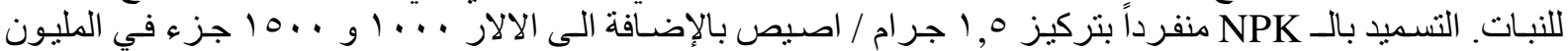

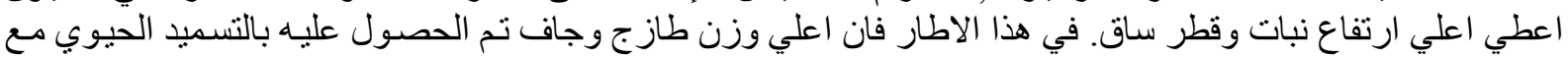

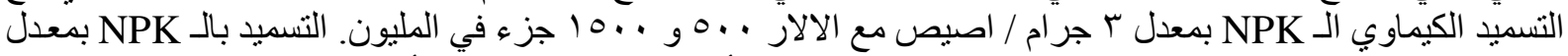

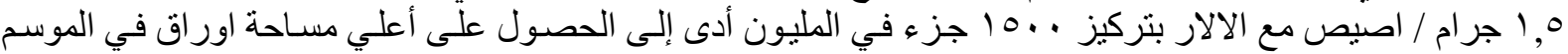

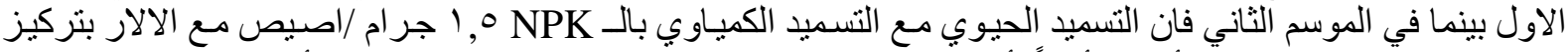

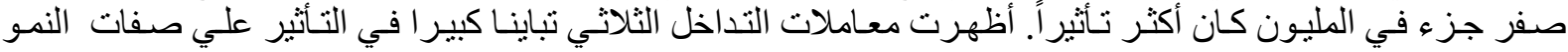

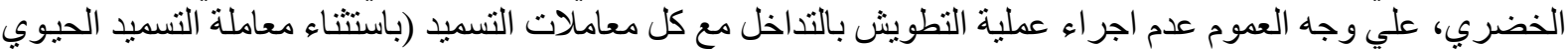

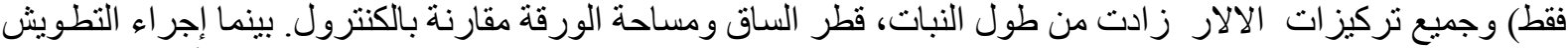

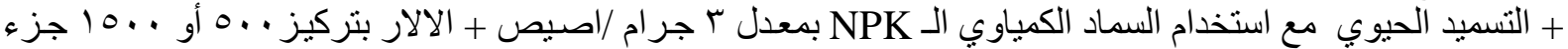
في المليون اعطي اعلي وزن طازج وجاف علي التوالي.

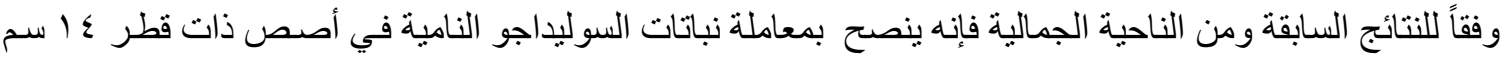

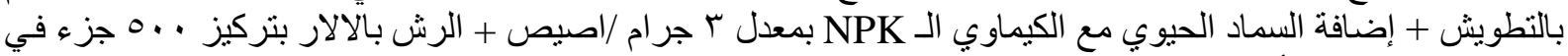

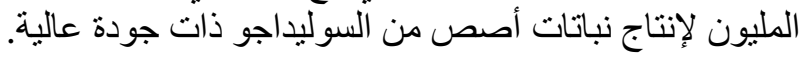




